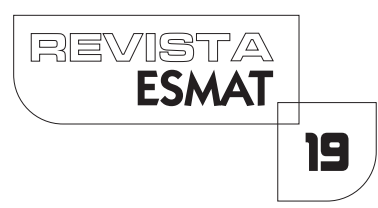

\title{
MICROSSISTEMA DAS PENAS ALTERNATIVAS: ANÁLISE GERENCIAL E NORMATIVA DA FASE COGNITIVA
}

MICROSYSTEM OF ALTERNATIVE SANCTIONS: MANAGEMENT AND NORMATIVE

ANALYSIS OF COGNITIVE STAGE

Ricardo Gagliardi

Mestre em Prestação Jurisdicional e Direitos Humanos (UFT). Especialista em Criminologia. Bacharel em Direito. Juiz de Direito (TJTO). Gestor Público. Pesquisador. gagliardi@tjto.jus.br.

Patrícia Medina

Doutora em Educação (UFG). Mestre em Administração de Sistemas Educacionais (PUCRS). Pedagoga e bacharel em Direito. Professora da Fundação Universidade Federal do Tocantins (UFT), vinculada ao Colegiado do Curso de Pedagogia e ao Programa de Pós-Graduação em Prestação Jurisdicional e Direitos Humanos (PPGPJDH), da Universidade Federal do Tocantins (UFT) e Escola Superior da Magistratura Tocantinense (ESMAT).patriciamedina@uft.edu.br

\section{RESUMO}

Alicerçado em investigação exploratória e predominantemente quantitativa, o estudo diagnostica o microssistema de penas alternativas em todas as comarcas de menor porte do estado do Tocantins, em sua fase processual cognitiva, a partir dos parâmetros da eficiência e da eficácia. A pesquisa documental, relacionada à busca de ações e execuções penais, concatenou-se com os processos baixados entre os anos de 2015 e 2016, como critério de corte. Paralelamente, empreenderam-se revisões sistemáticas de literatura e de jurisprudência. Sua base teórica identifica-se ao modelo criminológico de terceira geração das inter-relações sociais, especialmente à teorização da criminologia clínica de inclusão social. Conclui-se que o microssistema das penas alternativas está em pleno funcionamento e tem amplas condições de melhorias. Há uma adequada estrutura de meios e de pessoal. De outro modo, detectam-se problemas de tempo na tramitação do processo (morosidade extrema) e de qualidade quanto aos padrões estabelecidos. $\bigcirc$ funcionamento do serviço não pode ser considerado eficiente e eficaz na perspectiva gerencial; portanto, não se demonstra efetivo. Na perspectiva normativa, sua ineficácia está adstrita a algumas hipóteses legais. 
PALAVRAS-CHAVE: Microssistema de Penas Alternativas. Processo Penal. Aplicação de Penas Restritivas. Eficiência. Eficácia.

\begin{abstract}
This study, relying on a mainly quantitative exploratory research, diagnoses the microsystem of alternative sanctions in all small judicial districts of the state of Tocantins. It focuses on the cognitive procedural phase, based on efficiency and efficacy parameters. A desk research of criminal proceedings and executions was concatenated with the lawsuits filed between the years 2015 and 2016, as a cutoff criterion. Concurrently, systematic reviews of literature and jurisprudence were undertaken. Its theoretical background identifies itself to the third-generation criminological of social interrelationships, regards especially to the clinical criminology model of social inclusion. It concludes that the Microenvironment of Alternative Sanctions is in full operation and it has many conditions for improvements. There is an appropriate structure of material and personal resources. But there are time procedure problems (extreme delays) and quality problems concerning stablished standards. The operation of the service cannot be considered efficient and efficacious in managerial perspective and therefore has not been proven effective. In the normative perspective, its inefficacy is attached to some legal hypotheses.
\end{abstract}

KEYWORDS: Alternative Sactions Microenvironment. Criminal Procedure. Restrictive Sentencing. Efficiency. Effectiveness.

\title{
I CONSIDERAÇÕES INICIAIS
}

$\bigcirc$ estudo volta-se à pesquisa sobre o microssistema de penas alternativas, delimitado à fase do processo de conhecimento.

microssistema analisado segue preceitos gerais, tem alicerces na Constituição da República Brasileira e nas normas penais e processuais penais. De outra forma, em seu íntimo, tem elementos normativos, estrutura, funções, atividades - próprios e padronizados - diversos das demais penas criminais, princípios deontológicos, objetivos e regras de conduta diversas, pois mais próximo de satisfazer a amplitude do princípio da dignidade da pessoa humana, com a ambição de obter melhores resultados psicossociais para quem recebe a pena, para a vítima e à sociedade (GAGLIARDI, 20 I 8, p. 42).

microssistema, assim, estabelece-se e influencia o processo penal nos casos em que a pena aplicada tem o patamar de até quatro anos ou - até em valores superiores se há a substituição da pena privativa de liberdade por penas restritivas de direito. 
Por sua vez, o processo de conhecimento na seara criminal relaciona-se à fase da análise e formação da convicção da culpa ou da inocência do réu.

Desenvolve-se, em regra, desde a formação da opinio delicti pelo Ministério Público que dá início à ação penal, com o recebimento da denúncia, o processamento penal até a prolação da sentença ou decisão judicial terminativa.

No entanto, a experiência tem indicado que há dificuldades na aplicação das penas alternativas, tendo em vista a alta demanda acumulada do serviço e a ausência de melhores instrumentos de gestão. Isso é constatado também segundo estudos de vários autores (REALE JÚNIOR, 2013, p. 374-375; OLIVEIRA etal, 2002, p. 54).

Bitencourt (2007, p. 498) foi mais à frente. Argumentou que a má aplicação das penas alternativas motivará a impunidade e o consequente aumento da criminalidade, o que dará ensejo a novas exasperações penais e o recrudescimento da política criminal do terror, o que significa mais encarceramento.

A exploração da pesquisa de dados buscou desvendar a organização do serviço, no âmbito estrutural e alusivo aos fluxos procedimentais e rotinas, e ainda respeitante à aplicação da pena propriamente dita.

Assim, a descrição e a análise dos dados procederam dessa forma, em três partes.

No que concerne ao campo estrutural, apenas foi contemplada neste trabalho de pesquisa a visualização da estrutura do Poder Judiciário. Não foram coletados dados sobre as instituições que exercem funções essenciais à justiça.

$\mathrm{Na}$ esfera dos fluxos e rotinas procedimentais, foram analisados: os prazos procedimentais e processuais por fases do procedimento e do processo judicial, a orientação e o controle dos órgãos superiores às comarcas, e o grau de complexidade dos processos. Outras rotinas procedimentais foram analisadas, porém, conjuntamente com o ambiente das penas propriamente ditas.

Atinente à área da aplicação das penas propriamente ditas, desenvolveu-se uma categorização em quatro partes: i) Classificação das sentenças por espécies de veredictos; ii) Classificação das sentenças condenatórias; iii) Classificação das penas criminais não substituídas; iv) Classificação das penas alternativas aplicadas.

Durante a análise dos dados, o cuidado remonta à comparação pragmática dos dados tabulados com os paradigmas dogmático-jurídicos, observando-se as bases teóricas alicerçadas nas perspectivas criminológicas da inter-relação social (PIRES; DIGNEFFE, 1992, 37-43) e do modelo de criminologia clínica de inclusão social (SÁ, 2015).

Por fim, propugna observar, a fim de cumprir os objetivos talhados, os argumentos da teoria administrativa acerca da eficiência, da eficácia e da efetividade (BRESSERPEREIRA, 2000).

\section{METODOLOGIA}

objetivo principal do estudo foi o de diagnosticar o microssistema das penas alternativas nas comarcas de $1^{\mathrm{a}}$ e $2^{\mathrm{a}}$ entrâncias do estado do Tocantins, Brasil, em seu 
aspecto organizacional, atinente à fase da aplicação da pena, a partir dos parâmetros da eficiência e da eficácia. Pelo modo da indução, pressupõe-se a probabilidade de que em tantas outras localidades espalhadas pelo Brasil haja comportamentos assemelhados.

Secundariamente, pretendeu-se descrever as principais características estruturais e relacionadas aos fluxos e às rotinas procedimentais, da aplicação da pena propriamente dita, bem assim analisar as condições que facilitam ou dificultam o funcionamento do serviço de penas alternativas, de forma eficiente, eficaz e efetiva.

O estudo foi realizado com todas as vinte e oito comarcas de menor porte do estado do Tocantins. Estas se referem às de primeiras entrâncias instaladas: Almas, Araguacema, Aurora do Tocantins, Axixá do Tocantins, Figueirópolis, Goiatins, Itacajá, Novo Acordo, Pium, Ponte Alta do Tocantins, Tocantínia, e Wanderlândia; e às de segundas entrâncias instaladas: Alvorada, Ananás, Araguaçu, Arapoema, Augustinópolis, Colmeia, Cristalândia, Filadélfia, Formoso do Araguaia, Itaguatins, Miranorte, Natividade, Palmeirópolis, Paraná, Peixe e Xambioá.

Segundo classificação utilizada pelo IBGE (BRASIL, 20I8), municípios de pequeno porte são os que possuem até 20 mil habitantes. Segundo censo, ano 20 I 0, 17, 1 \% (ou 32.660.247 em números absolutos) da população brasileira vivem em municípios de pequeno porte. Essas espécies de municípios são a maioria no Brasil (3.914 em números absolutos e 70,4\% em números relativos). Os municípios que compõem as comarcas a serem estudadas possuem até 20 mil habitantes.

A pesquisa documental, relacionada à busca de ações penais, concatenou-se com os processos baixados entre os anos de 2015 e 2016, como critério de corte. A limitação de tempo da pesquisa documental nos processos judiciais baixados, a partir de 2015 , relaciona-se ao fato da data em que todos os processos das comarcas de $1^{\mathrm{a}}$ e $2^{\mathrm{a}}$ entrâncias foram digitalizados, tornando todos os processos eletrônicos. As metas do primeiro grupo para a digitalização encerrou-se em 15/7/20|4, conforme Portaria TJTO I656/2014 (BRASIL, 2014). As do segundo, em 30/9/2014, estabelecida mediante a Portaria TJTO 2056/20 I 4 (TOCANTINS, 20 I 4). A coleta de dados a partir de processos eletrônicos gerou maior facilidade de acesso e de manuseio e ainda menor custo à pesquisa.

Como fontes metodológicas de pesquisa, foram consideradas a pesquisa documental e a revisão sistemática de literatura. Quatro foram as fontes de pesquisa documental.

A primeira, representada por meio de questionário, direcionada à Presidência do Tribunal de Justiça do Estado, à Corregedoria Geral de Justiça (CGJUS) e ao Grupo de Monitoramento e Fiscalização (GMF), refere-se a quatro variáveis reconhecidas pelo código "O", trata de perguntas a respeito da orientação e do controle dos órgãos reguladores sobre os serviços correlatos realizados pelas comarcas, e sobre a estrutura de apoio para o cumprimento de pena.

A segunda, revelada por meio de formulário, refere-se a sete variáveis reconhecidas pelo código "EPA", correlacionadas ao banco de dados de ações penais baixadas, denominada "e-Proc - ações penais baixadas". 
A terceira, estampada por meio de um formulário, circunscreve-se a sessenta e sete variáveis reconhecidas pelo código "EP", atinentes ao banco de dados de execuções penais baixadas, denominada "e-Proc - execuções penais baixadas".

A quarta fonte de pesquisa adveio das respostas de ofícios encaminhados às Diretorias de Gestão do Tribunal de Justiça do Estado do Tocantins, como Diretoria de Gestão de Pessoas (DIGEP), Diretoria da Infraestrutura e Obras (DIINF) e Diretoria Financeira(DIFIN).

Os elementos que se relacionam ao Sistema de Processo Eletrônico (e-Proc) dispuseram de levantamento prévio, com o apoio da Coordenadoria de Gestão Estratégica, Estatística e Projetos (COGES), realizado de forma automatizada.

Iniciou-se a coleta de dados de forma manual, com vista a levantar informações de todas as ações penais de processos baixados entre os anos de 2015 e 20l6, como critério de corte, por meio de planilha, usando-se da ferramenta do Microsoft Office Excel 2007.

Nesse âmbito, processo baixado é termo mais amplo do que o arquivamento, pois inclui os casos como redistribuição ou cancelamento de distribuição, sem ser arquivado ou encerrado o processo.

Exclusões de dados coordenadas foram realizadas com relação aos bancos de dados "e-Proc - ações penais baixadas" -, em duas etapas. Inicialmente vieram o total de 8.804 processos pela Presidência/Coordenadoria de Gestão Estratégica, Estatística e Projetos (COGES).

Na primeira etapa, realizou-se a filtragem apenas dos processos com as seguintes competências, com o fim de selecionar apenas as ações penais: Criminal, Criminal//úri, Violência Doméstica contra a Mulher, Criminal/Entorpecentes, Criminal/Execução Penal, Juizados Especiais Criminais, restando 8.327 processos. Destes, excluíram-se as classes seguintes, totalizando 4. 123 processos excluídos: Execução da Pena, Habeas Corpus, Habeas Corpus (processo originário em meio eletrônico - distribuição interna), Justificação Criminal, Liberdade Provisória com ou sem fiança, Medidas Investigatórias sobre Organizações Criminosas, Medidas Protetivas - Estatuto do Idoso, Medidas Protetivas de urgência (Lei Maria da Penha), Pedido de Busca e Apreensão Criminal, Pedido de prisão preventiva, Pedido de prisão temporária, Pedido de quebra de sigilo de dados e/ou telefônico, Relaxamento de Prisão, Restituição de Coisas Apreendidas. Por fim, a base para ser analisada ficou com 4.204 processos. Esse procedimento correu junto com o Procedimento Administrativo SEI $\mathrm{n}^{\circ}$ 17.0.000007408-0/TJTO(TOCANTINS, 2017).

Na segunda etapa de exclusão, por não se relacionar ao objeto de estudo, foram separados os processos e excluídas as seguintes hipóteses: 34I, devido à aplicação de penas superiores a quatro anos e que não houve substituição de pena; 218 processos por não se tratar de ação penal, e sim por serem alusivos às cartas precatórias, aos pedidos ou incidentes processuais e a outros procedimentos; 108 casos por estarem duplicados a partir da busca eletrônica do COGES; 70 casos de litispendência 
reconhecida judicialmente; e 16 hipóteses de outros casos, sendo 6 de duplicação do processo no momento da digitalização, 2 de baixas equivocadas, 5 de processos baixados sem decisão judicial, I de coisa julgada reconhecida judicialmente, I de baixa de processo suspensos e I por duplicação durante a distribuição. Totalizaram-se 753 processos excluídos do banco de dados para a análise.

Por fim, o banco de dados final estacionou em uma amostra de $3.45 \mathrm{I}$ processos. Destes, observou-se que há mais de um réu em alguns processos, fazendo com que a base para a análise resultasse em 3.882.

A pesquisa bibliográfica foi realizada por meio das revisões sistemáticas de literatura e da jurisprudência nacional, a fim de se desvendar a produção científica que retrate modelos legais e de gestão durante a fase de aplicação de pena alternativa, bem como que se correlacione com o modelo da criminologia clínica de inclusão social. Esta abarcou a produção científica acerca do tema por meio de livros, artigos, dissertações e teses, nas bases de dados da biblioteca física da Escola Superior da Magistratura Tocantinense (ESMAT), e, de forma virtual, dos bancos de teses da Universidade de São Paulo (USP) e da Universidade Federal do Tocantins (UFT), por meio dos descritores selecionados, de forma conjunta ou alternada: pena alternativa, pena restritiva de direito, gestão e eficiência. Com relação à área jurídica foram também realizadas pesquisas nos bancos de jurisprudência dos Tribunais Superiores (STF e STJ), e ainda em alguns Tribunais estaduais.

Foi realizado estudo analítico de instrumentos normativos, manuais de condutas e pesquisas, produzidos ou encomendados por órgãos governamentais especializados, como Conselho Nacional de Justiça (CNJ), Departamento Penitenciário Nacional (DEPEN/MJ), Conselho Nacional de Política Criminal e Penitenciária (CNPCP), a partir de 2000.

A importância atribuída à fonte bibliográfica foi dar suporte para análises comparativas entre o ser e o deve-ser (paradigma), especialmente almejando uma possível padronização dos processos gerenciais envolvidos na problemática em estudo.

Atinente à sistematização das variáveis, entende-se o termo como as alternativas constantes de cada elemento do questionário e do formulário. São reconhecidas pelos códigos "O", "EPA" e "EP". Serviram como meio de diagnosticar a fase processual de conhecimento e a pena efetivamente aplicada.

A pesquisa foi ordenada a partir das referidas variáveis respondidas durante a pesquisa. Estas seguiram a prévia problematização inserida, conforme os passos abaixo definidos, em cada um dos critérios: eficiência e eficácia e efetividade.

Nessa sistematização, quando da análise da influência desses dois primeiros critérios, de forma individualizada, foram realizadas análises relacionadas ao objeto da pesquisa.

Produziram-se, então, as indagações nos contextos das áreas de estrutura do serviço, do fluxo e das rotinas procedimentais (organização do serviço), e da aplicação das penas alternativas propriamente ditas. 
A base paradigmática, a fim de dar um significado pragmático às variáveis, baseia-se em regras legais (especialmente Constituição Federal, Código Penal, Lei de Execução Penal e leis penais extravagantes), instrumentos normativos, jurisprudência e doutrina, e pesquisas e manuais de conduta (especialmente editados pelo TJTO, DEPEN/MJ, CNPCP e CNJ), e estudos científicos publicados no País, relacionados a modelos aplicados.

Com relação ao critério da eficiência, observaram-se as variáveis que compuseram os formulários, relacionadas ao fato de haver estrutura do serviço, como a quantidade de pessoas e meios suficientes para realizá-lo; serem cumpridos os fluxos e as rotinas procedimentais, como o cumprimento de prazos aritméticos previstos em lei; serem observados os preceitos de direito material e processual para a aplicação da pena, como a análise dos requisitos para a substituição da pena, o índice de sentenças de mérito com fixação de regime inicial aberto e/ou com substituição à pena alternativa, a fim de o serviço funcionar bem, de maneira razoável, esperada e padronizada (qualidade dos serviços).

Na primeira fase do critério da eficácia, orientou-se pelas variáveis que compuseram os formulários. Dois são os enfoques analisados acerca da eficácia: gerencial e normativo.

$\bigcirc$ primeiro trata da eficácia gerencial do microssistema, do ponto de vista organizacional, atinente ao funcionamento do serviço (CHIAVENATO, 20I4). Relaciona-se, de um lado, aos objetivos do processo penal adstrito ao microssistema; de outro, aos resultados produzidos, entre os quais o de se conhecer o índice de sentenças de mérito produzidas (veredicto de mérito, aquele em que se declara a inocência ou a culpa), excetuando-se da computação os relacionados às hipóteses legais despenalizadoras (composição civil de danos, transação penal, suspensão condicional do processo, renúncia ou retratação da representação, etc.), morte. Quer-se dizer que quanto maior for o índice de produção dessas espécies de sentenças, maior será o grau de eficácia.

Outro indicador de eficácia gerencial está em analisar os critérios de equilíbrio e justiça. $\bigcirc$ maior índice de equilíbrio, baseado nos fatores legais, gerará maior índice de eficácia.

O segundo enfoque da eficácia concerne ao aspecto normativo (HABER, 2007). Associa, de um lado, a própria norma; de outro, a correspondência prática de seus efeitos no microssistema, conforme os objetivos propostos pela lei. Quer-se entender se tal norma tem a capacidade de produzir efeitos, em seu aspecto normativo (validade conforme e dentro dos limites da lei), e sociológico (legitimidade reconhecida pelos destinatários).

A coleta e a análise dos dados foram realizadas a partir de três eixos focais: i) estrutura do serviço; ii) fluxos e rotinas processuais e procedimentais; e iii) aplicação da pena propriamente dita. 
Os dados coletados foram codificados, tabulados, processados, e analisados, por meio do programa Microsoft Office Excel e Programa Estatístico "R", com tratamento predominantemente quantitativo. As informações foram ordenadas por tabulações simples e cruzadas de até três variáveis para análise comparativa dos dados, e as bases paradigmáticas.

A análise de dados se desenvolveu por meio de descrição estatística. Os resultados foram apresentados utilizando-se de gráficos, histogramas, tendo por base tabelas.

Para o cálculo de tempo, correspondentes aos prazos das fases procedimentais, utilizaram-se os conceitos de média aritmética, de mediana e de desvio padrão.

A média aritmética de um conjunto de valores é "a medida de centro encontrada pela adição dos valores e divisão do total pelo número de valores". "Essa definição pode ser expressa pela fórmula a seguir: média $=\left(\sum x\right) / n$ ". "Em que, $\sum$ indica a adição de um conjunto de valores; $x$ é a variável, em geral usada para representar os valores individuais dos dados; n representa o número de valores em uma amostra" (TRIOLA, 2005, p. 45).

A mediana de um conjunto de dados é "medida de centro que é o valor do meio quando os dados originais estão arranjados em ordem crescente (ou decrescente) de magnitude". (TRIOLA, 2005, p. 46).

"O desvio padrão de um conjunto de valores amostrais é uma medida da variação dos valores em torno da média. É uma espécie de desvio médio dos valores em relação à média, que é calculado [...]" pela fórmula: "s $=\sqrt{ }\left(\left(\sum(x-x \quad)^{\wedge} 2\right) /(n-I)\right)$ " (TRIOLA, 2005, p. 57).

Algumas observações acerca do desvio padrão devem ser anotadas:

- $\quad$ O desvio padrão é uma medida da variação de todos os valores a partir da média;

- O valor do desvio padrão é, usualmente, positivo. É zero apenas quando todos os valores dos dados são o mesmo número. Também, maiores valores de s indicam maiores quantidades de variação;

- $\quad$ O valor do desvio padrão s pode crescer dramaticamente com a inclusão de um ou mais outliers (valores de dados que estão muito afastados dos demais) (TRIOLA, 2005, p. 57).

Tendo em vista os efeitos dos outliers, em uma primeira análise dos dados eles foram excluídos, para fins de se calcularem medidas de centralidade (média e mediana) e de dispersão (desvio padrão).

$\bigcirc$ acesso aos dados e ao sistema e-Proc foi requerido e autorizado pelo presidente do Tribunal de Justiça do Estado (Processo SEl n 17.0.000007408-0 TJ/TO). Um formulário piloto testou o roteiro de levantamento de dados. Um roteiro estruturado conduziu o pesquisador na sequência dos dados a serem coletados, sendo preenchido de forma linear. 
Os dados foram apresentados, integrando uma resposta geral do microssistema, abrangendo a área espacial da pesquisa, de modo a não gerar exposição desnecessária dos gestores judiciários.

\section{DESCRIÇÃO DOS RESULTADOS E DISCUSSÃO}

\section{I Da estrutura do serviço}

Gráfico I - Estrutura de pessoal das serventias criminais - Comarcas de menor porte do Estado do Tocantins, 2018.

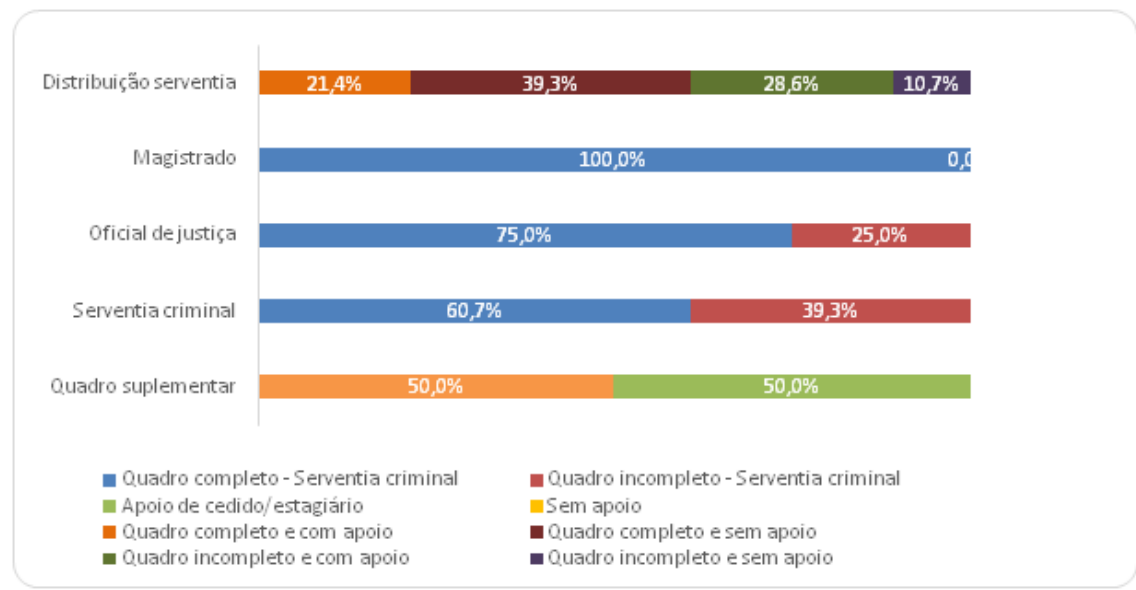

Fonte: Elaborada pelo autor a partir de dados obtidos da DIGEP - TJTO - atualizada em 5/6/20 I 8

De acordo com a Lei Complementar Estadual no 10, de 1996, e anexo III (TOCANTINS, 1996), cada serventia criminal deve contar ao menos com um juiz de direito, um escrivão (chefe de cartório), um técnico judiciário e dois oficiais de justiça. Ressalve-se que o efetivo da serventia criminal não atua especificamente nas atividades circunscritas ao microssistema, mas também em todas as atividades relacionadas à justiça criminal.

Todas as comarcas possuem o quadro completo de juízes. No entanto, em duas delas o juiz é substituto. Para fins de estar o quadro completo foi considerado o número de um juiz, independentemente de ser titular.

$\bigcirc$ quadro de oficiais de justiça está 75\% completo. Em seis delas somente há um oficial de justiça. Em uma delas não há oficiais de justiça. Foi considerada completa a composição de pelo menos dois oficiais de justiça.

Com relação aos servidores que atuam diretamente na serventia criminal, verificouse que $60,7 \%$ das serventias criminais das 28 comarcas de primeira e segunda entrâncias 
estão com a estrutura completa, conforme o paradigma legal. Por sua vez, 39,3\% delas estão com a estrutura incompleta.

Importa observar, no entanto, que metade das referidas serventias conta com uma estrutura de pessoal suplementar, por meio de funcionários cedidos de outros entes, como municípios e Estado, e/ou estagiários, ou até com excedente de funcionários efetivos. Nessa senda, apenas três das serventias que estão sem o quadro efetivo completo não possuem estrutura de apoio suplementar, o que corresponde a 27,3\% da categoria (do quadro incompleto), ou 10,7\% das comarcas estudadas.

Ressalta-se informar terem sido consideradas como quadro completo da serventia criminal não somente a composição formada por um escrivão e um escrevente/técnico judiciário, mas também a composição que compreende dois ou três escreventes/técnicos judiciários.

Não há comarcas em que há ausência plena de estrutura de pessoal para a realização do serviço.

A média dos três grupos (juiz, oficiais de justiça e serventia criminal, suprida por quadro de apoio) resulta em $89,3 \%$ das comarcas com efetivo completo ou suprido.

Gráfico 2 - Estrutura física predial, climatização e servidor informatizado das serventias criminais - Comarcas de menor porte do Estado do Tocantins, 2018.

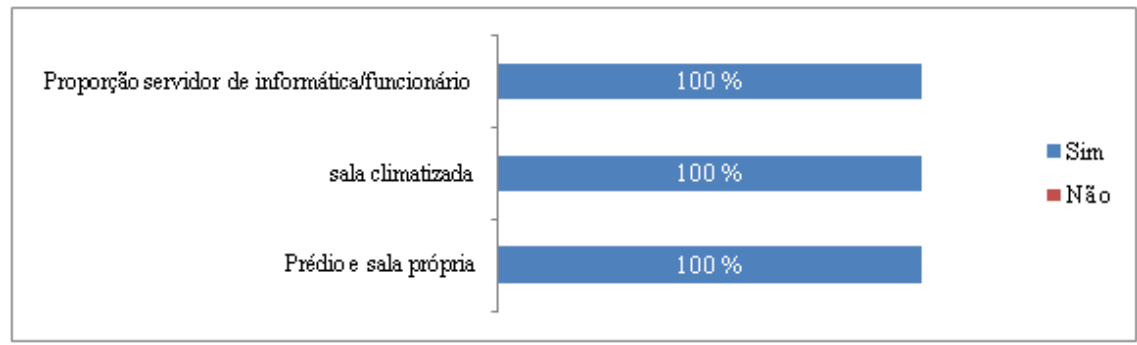

Fonte: Elaborada pelo autor a partir de dados obtidos do TJTO - atualizada em 28/5/20 I 8

esquema gráfico acima descreve a estrutura física relacionada à existência de prédio do Fórum, a existência de sala própria para o funcionamento das serventias criminais, ainda averigua se as salas onde funcionam as serventias são climatizadas, considerando-se temperatura média do ar no Estado entre 26 e $28^{\circ} \mathrm{C}$ (TOCANTINS, SEPLAN-TO, 20।8), e se há um servidor de informática para cada funcionário, tendo em vista a plataforma exclusivamente eletrônica de processos.

Segundo os resultados apresentados pela Diretoria de Patrimônio, 100\% das unidades judiciárias possuem os quatro elementos acima descritos.

De acordo com estudos, o estabelecimento de um plano de manutenção preventiva e corretiva é fundamental para a garantia da eficiência e da eficácia (CARPINETTI; GEROLAMO, 2017, p. 80), assim como o Tribunal de Justiça tem realizado. 


\subsection{Fluxos e rotinas procedimentais}

As regras paradigmáticas com relação aos fluxos e as rotinas procedimentais acerca da fase da aplicação da pena são o Código de Processo Penal, a Lei n 9.099, de 1995, o Código Penal, Código de Processo Penal, e as leis extravagantes penais.

Histogramas 0I - Tempo de cumprimento do procedimento - a partir da data da denúncia Comarcas de menor porte do Estado do Tocantins, execuções penais baixadas entre os anos de 2015 e 2016.
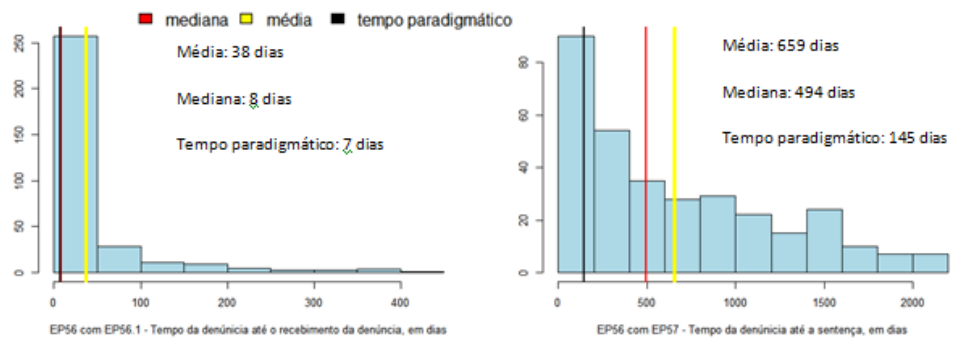

Fonte: Elaborada pelo autor a partir de dados obtidos nas tabelas EP56, EP56. I e EP57, extraídas do sistema e-Proc TJTO, ano 2017.

Histogramas 02 - Tempo de cumprimento do procedimento - a partir da data do fato comarcas de menor porte do Tocantins - execuções penais baixadas - anos 2015 e 2016.

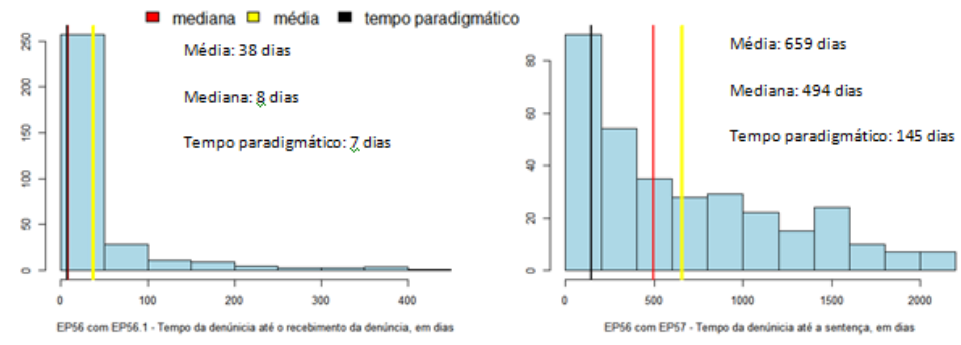

Fonte: Elaborada pelo autor a partir de dados obtidos nas tabelas EP56, EP56. I e EP57, extraídas do sistema e-Proc TJTO, ano 2017. 
Histogramas 02 - Tempo de cumprimento do procedimento - a partir da data do fato - comarcas de menor porte do Tocantins - execuções penais baixadas - anos 2015 e 2016.
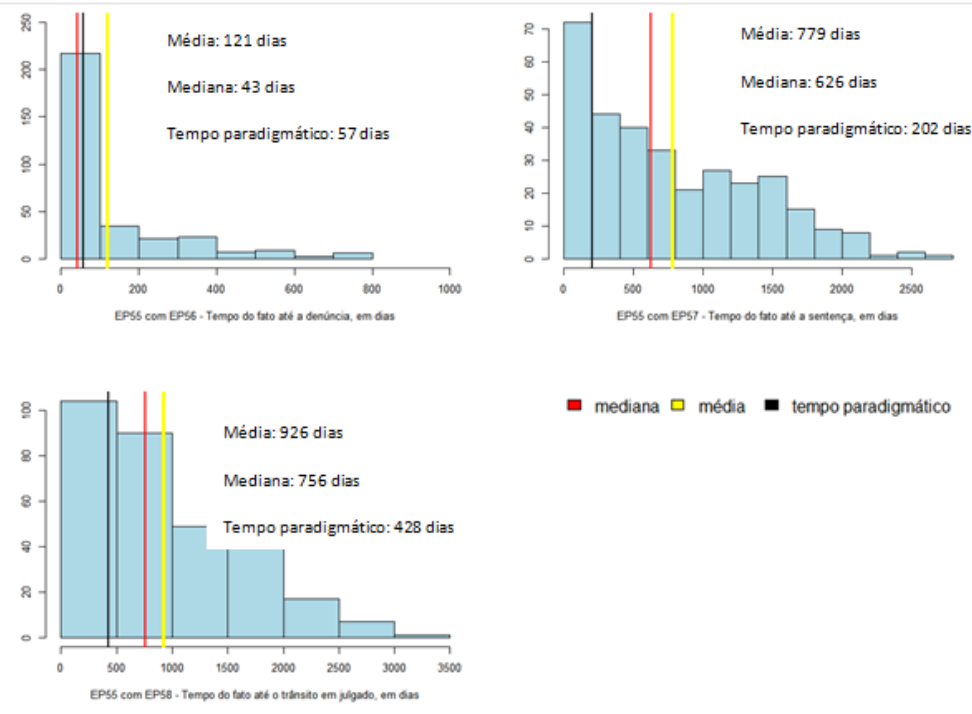

- mediana $\square$ média $\mathbf{a}$ tempoparadigmático

Fonte: Elaborada pelo autor - dados obtidos nas variáveis EP55, EP57, EP58 - sistema e-Proc TJTO, ano 2017.

Os histogramas acima, elaborados a partir da extração dos dados das tabelas referentes à EP.55 e à EP.58, conjugados com à EP.66, extraídas do banco de dados "eProc - processos de execução baixados" -, têm o condão de contribuir com especialmente o parâmetro da eficiência, e evidenciar elementos de estudos aos parâmetros da eficácia e da efetividade.

Uma observação relevante deve ser levantada, como ressalva. O referido banco de dados informado trata das execuções penais baixadas entre os anos 2015 e 2016 . 0 estudo do declarado banco gerou conhecimentos atinentes às fases, pré-processual, e do processo judicial de conhecimento, até mesmo os de atos realizados há mais de 10 anos, quando o processo judicial não estava inserido em plataforma eletrônica nem havia a mesma estrutura e organização atual.

gráfico relaciona o tempo de cada fase procedimental e o tempo total de transcurso processual entre a data de denúncia até à da sentença. Mostra ainda o tempo da data do fato até à do trânsito em julgado, perpassando por todas as fases de conhecimento da persecução penal, abrangendo a fase do registro da ocorrência, da investigação policial, da análise do caso e oferecimento da denúncia pelo Ministério Público, a análise e recebimento da denúncia pelo juiz competente, os atos de citação e 
realização de defesa preliminar, a reiteração da denúncia, a fase de audiência de instrução e julgamento, e, porfim, o trânsito em julgado.

Da mesma forma que o índice de prescrição da pretensão punitiva, esta como resultado da eficácia (analisado no subitem 3.3.1), importante se faz analisar os dados relacionados ao tempo de transcurso do processo, a partir do paradigma legal, atinente aos prazos aritméticos previstos em lei, a fim de avaliar um dos fatores do processo de gestão (fluxos de tempo das funções e tarefas), componente da eficiência.

Como referência aos referidos prazos, as leis de regência são o Código de Processo Penal, a Lei n I.419, de 2006, e Lei Complementarn 80, de 1994.

Segundo estudo realizado (GAGLIARDI, 2017, p. 217-219), considerando-se as peculiaridades de estar o réu solto, a defesa ser realizada pela Defensoria Pública (prazos em dobro) e ainda ser caso de rito ordinário (prazo mais alongado), o tempo do registro do fato até a data da denúncia seria de 57 dias. $O$ tempo entre a denúncia oferecida até o seu recebimento pelo juiz competente é de até 7 dias. $\bigcirc$ tempo entre a data da denúncia e à da sentença é de até 145 dias. O tempo entre a data do registro do fato até à da sentença é de até 202 dias, com os mesmos pressupostos.

Os prazos aritméticos atuam como um padrão aceitável para a maior parte dos feitos, ainda mais se considerando que os crimes apurados são de menor complexidade (pena aplicada de até quatro anos). Por isso, servem como indicador paradigmático, para fins do presente estudo.

tempo entre a data do fato até o trânsito em julgado é de até 428 dias. Para tal, utilizou-se do prazo de 202 dias entre a data do fato até à da sentença. A partir daí, há dois procedimentos, antes da remessa do recurso de apelação ao Tribunal de Justiça e depois da remessa. No primeiro período há definição legal dos prazos. No segundo, no entanto, não há, e por isso houve a definição com base em uma razoabilidade, baseado nos prazos processuais do primeiro grau. Compilaram-se os seguintes prazos: 10 dias para a apresentação do pedido recursal (Defensoria Pública) - 2 dias para a escrivania receber e passar os autos conclusos - 5 dias para o recebimento recursal pelo juiz - 2 dias para a escrivania tomar providências e intimação - 10 dias para iniciar o prazo de intimação no processo eletrônico - 16 dias para a apresentação das razões recursais - 2 dias para a escrivania tomar providências e intimação - 10 dias para iniciar o prazo de intimação no processo eletrônico - 8 dias para a apresentação das contrarrazões recursais - 2 dias para a escrivania tomar providências de remessa ao Tribunal de Justiça - 2 dias para a Secretaria do Gabinete de Desembargador passar os autos conclusos - 5 dias para o recebimento recursal pelo relator - 2 dias para a Secretaria providenciar a intimação do Ministério Público - 10 dias para iniciar o prazo de intimação no processo eletrônico - 5 dias para o Ministério Público se manifestar - 2 dias para a Secretaria passar conclusos os autos - 30 dias para elaboração de relatório e voto - 2 dias para a Secretaria passar os autos conclusos ao revisor - 10 dias para iniciar o prazo de intimação no Processo Eletrônico - 30 dias para elaboração de relatório e voto pelo revisor - 2 dias para a Secretaria providenciar a data do julgamento - 60 dias até a data do julgamento. 
Para retratar os dados, parte-se de cinco períodos: da data do fato até à do oferecimento da denúncia, da data da denúncia até o seu recebimento, da data da denúncia até à da sentença, da data do fato até à da sentença e da data do fato até o trânsito em julgado da sentença. Utilizou-se das técnicas estatísticas da mediana, do terceiro quartil, e da média para comparar os dados.

Os resultados demonstraram que, da data do fato até à do oferecimento da denúncia, a mediana foi de 43 dias, o terceiro quartil foi de 165 dias, e a média de I 2 I dias. $\bigcirc$ paradigma legal se perfaz em 57 dias. Ou seja, até $50 \%$ dos processos estão dentro do padrão legal. Porém, considerando a média, o prazo superou 212\% do padrão. Em pesquisa do IPEA (20।5, p. 39), o tempo médio entre a instauração do inquérito e a denúncia foi de 135 dias (4,5 meses). A média tocantinense das comarcas de pequeno porte anuncia-se melhor que a média nacional.

Da data da denúncia até o seu recebimento, a mediana foi de 8 dias, o terceiro quartil foi de 29 dias, e a média de 38 dias. $O$ paradigma legal se perfaz em 7 dias. Até $50 \%$ dos processos superou o índice em $22 \%$ dos casos. Na média, ultrapassou-se o valorem $536 \%$.

Da data da denúncia até à da sentença, a mediana foi de 494 dias, o terceiro quartil foi de 1.057 dias, e a média de 659 dias. O paradigma legal se perfaz em I 45 dias. Até 50\% dos processos ultrapassam o prazo legal, no máximo, em 341\%. Na média, o valor percentual eleva-se para 454\%. Enquanto que a pesquisa do IPEA (20 I 5, p. 39) revelou que o tempo médio entre o oferecimento da denúncia pelo Ministério Público e a sentença de extinção do processo é de 22 meses ou 660 dias, ou seja, quase dois anos. A média tocantinense das comarcas de pequeno porte revela-se praticamente igual à da média nacional.

Da data do fato até à da sentença a mediana foi de 626 dias, o terceiro quartil foi de I.235 dias, e a média de 779 dias. O paradigma legal se perfaz em 202 dias. Até 50\% dos processos ultrapassam o prazo legal, no máximo em 310\%. Na média, o valor percentual eleva-se para 386\%. A pesquisa do IPEA (2015, p. 39) informou que o tempo médio entre a instauração do inquérito e a sentença de extinção do processo é de 28,6 meses, o que significa 858 dias, acima da média tocantinense.

Da data do fato até o trânsito em julgado da sentença, a mediana foi de 756 dias, o terceiro quartil foi de 1.464 dias, e a média de 926 dias. $\bigcirc$ paradigma legal se perfaz em 428 dias. Até $50 \%$ dos processos ultrapassam o prazo legal, no máximo em 177\%. Na média, o valor percentual eleva-se para $216 \%$.

O mesmo estudo (GAGLIARDI, 2017, p. 212-213), assentado na jurisprudência, demonstra que os prazos processuais penais, de acordo com a hipótese em concreto, poderão sofrer alterações, sem que isso viole os parâmetros legais, a partir de um juízo de razoabilidade.

É preciso, assim, avaliar se houve ou não complexidade nos processos para se delimitar o tempo de transcurso processual. Essa complexidade refere-se a qualquer motivo que justifique o maior tempo para a finalização dos atos processuais. 
Gráfico 03 - Grau de complexidade processual / número de motivos, nas comarcas de menor porte do Estado do Tocantins, a partir das execuções penais baixadas entre os anos 2015 e 2016.

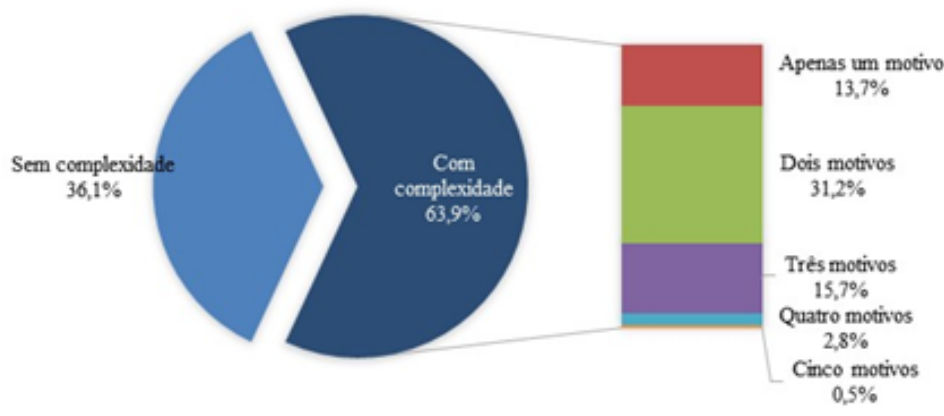

Fonte: Elaborada pelo autor - dados obtidos na tabela EP.66, extraída do sistema e-Proc TJTO, ano 2017.

Para a análise, extraiu-se da consideração de complexidade o fato de o réu ser defendido pela Defensoria Pública, pois já se estão considerando os prazos de defesa paradigmáticos em dobro, especialmente por serem padronizados.

Dos 388 processos analisados, referenciando a tabela EP66, do banco de dados "eProc - processos de execução baixados" -, observando-se o número de processos descritos, 36,1\% foram considerados sem qualquer fator de complexidade (140 incidências).

Foram considerados processos complexos o total de 63,9\%. Do número total dos processos analisados, 13,7\% dos processos (53 incidências) tiveram apenas um item de complexidade. 31 , 2\% dos processos totais ( 121 incidências) trouxeram dois motivos de complexidade. 15,7\% dos processos (6I incidências) anotaram três motivos de complexidade. $2,8 \%$ dos processos (I I incidências) conceberam quatro motivos. Por fim, $0,5 \%$ dos processos ( 2 incidências) estabeleceram cinco motivos referentes ao maior tempo de duração do processo. 
Gráfico 04 - Espécies dos motivos das complexidades / Tipo de campo jurídico, nas comarcas de menor porte do Estado do Tocantins, a partir das execuções penais baixadas entre os anos 2015 e 2016.

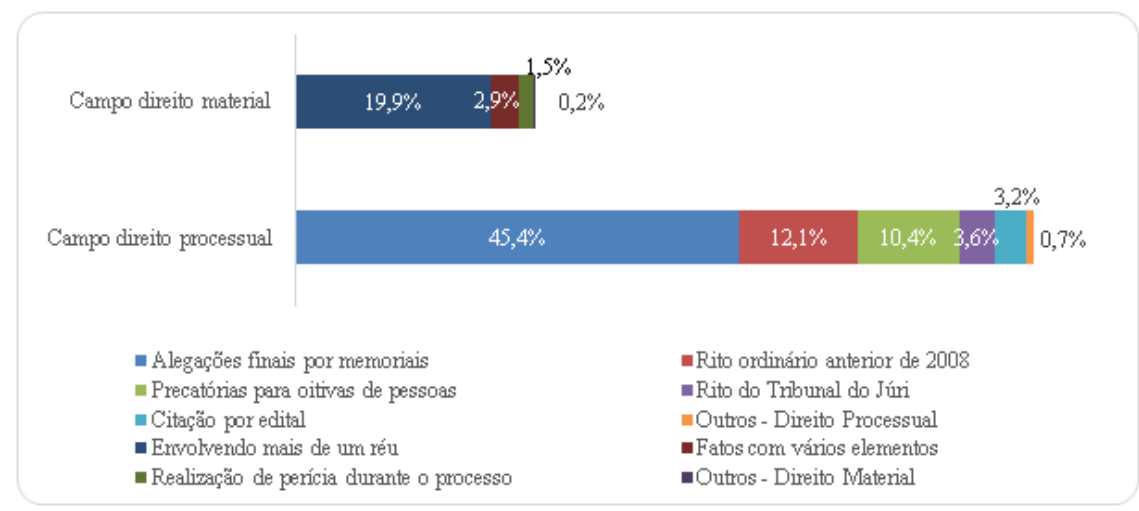

Fonte: Elaborada pelo autor - dados obtidos na tabela EP.66, extraída do sistema e-Proc TJTO, ano 2017.

Foram considerados no total $4 \mid 2$ elementos de complexidades nos processos.

Os itens de complexidade mais comuns foram em ordem decrescente: alegações finais por meio de memoriais (45,4\%), envolvendo mais de um réu (19,9\%); rito ordinário de procedimento anterior a 2008 ( I 2, I\%); precatórias para citação, intimação e oitiva de pessoas ( $10,4 \%$ ); rito do Tribunal do Júri (3,6\%); fatos narrados na denúncia envolvendo vários elementos (dias, pessoas, fatos) e citação por edital (3,2\%); realização de perícia durante o processo ( $1,5 \%)$; fatos de difícil prova $(0,2 \%)$, sendo os demais casos considerados irrelevantes $(0,7 \%)$.

Correlacionando estes aos dados referentes ao tempo do processo de conhecimento (gráficos 4 e 5), que justificou de certa forma o descumprimento do prazo aritmético legal, faz-se necessário asseverar alguns fatores.

A apresentação de alegaç̃̃es finais por meio de memoriais exige mais tempo. A regra é a realização da defesa final durante a audiência de instrução, por meio audiovisual. Porém, esse tempo, supostamente observando-se os mesmos prazos aritméticos, levaria o processo a mais 65 dias (GAGLIARDI, 20 I7, p. 2 I 8). Sendo esta a causa para quase metade do que se considerou como elemento de mais complexidade, e que justificou uma maior demora no andamento processual, ela, por si, doutro modo, não fundamenta com razoabilidade os altos índices de violação do prazo processual aritmético.

Há outros motivos, além das alegações finais, que incidiram com mais relevância, como o processo contra mais de um réu, ainda mais quando há mais de um advogado. Nesse caso, o trâmite processual pode gerar mais tempo, diante de a necessidade de 
maior movimentação cartorária haver duas defesas, possibilidade de um número maior de testemunhas, mais interrogatórios e a necessidade de um maior esforço intelectual por parte dos envolvidos, especialmente do juiz, durante a condução do processo e da elaboração da sentença. Porém, em raras exceções, durante a coleta de dados, arriscase vislumbrar hipóteses de severas complexidades que exigissem um tempo muito além do prazo aritmético legal.

Outro fundamento relativo à complexidade originou-se da citação e da intimação por meio de carta precatória (10,4\%). Embora tenha incidido apenas 43 vezes, o fato de as pessoas que interessam ao processo residirem fora da jurisdição da comarca causam mais demora no cumprimento e na conclusão dos atos processuais. Ainda faltam instrumentos de comunicação mais céleres entre os Estados da Federação e entre as esferas da Justiça.

O motivo do rito ordinário anterior a 2008 também tem relevância, embora menor, especialmente porque abrangeu apenas $12,1 \%$ dos itens dos fundamentos da complexidade. Isso ocorreu especialmente porque em 2008 o rito ordinário foi alterado, sendo desenvolvido um procedimento mais célere. Em vez de se realizarem três audiências de instrução e se manterem as alegações finais por meio de memoriais, a alteração criou o modelo de audiência una, e as alegações finais por meio audiovisual. Esse rito gerava a possibilidade de por vezes se triplicar o prazo processual, diante da necessidade de se agendarem três audiências mediante as dificuldades de pauta.

Por conseguinte, mesmo que se considere apenas a mediana, conforme demonstram os gráficos 4 e 5, há elevado grau de excesso de prazo, superior em mais de $200 \%$ em alguns casos comparado ao prazo aritmético legal (exceto do período entre a data do fato e a do recebimento da denúncia). E esse excesso não tem justificativa fulcral nos motivos referentes às complexidades, diante dos fundamentos supracitados.

Acrescente-se ainda que a análise da complexidade possa ser denotada em duas orientações relacionadas ao direito processual e ao direito material. A primeira orientação traduz-se em situações que podem ocorrer na esfera processual durante o decorrer de seu trâmite, como: precatórias para a intimação e oitiva de pessoas, defesa pela Defensoria Pública (prazo em dobro), alegações finais por meio de memoriais, defesas ou petições protelatórias, aditamento da denúncia, citação por edital e necessidade de suspensão do processo, rito mais complexo do Tribunal do Júri, rito ordinário anterior a 2008, suspensão condicional do processo descumprida. A segunda orientação, atinente ao aspecto de direito material, está consubstanciada em haver mais de um réu, fatos narrados na denúncia envolvendo vários elementos (dias, pessoas, fatos), fatos de difícil prova, realização de perícias. Esses elementos em geral causam maior tempo processual.

Como se verifica no gráfico acima, em geral, os motivos de complexidade são afetos à área processual $(75,4 \%)$ e não na de direito material (24,6\%), o que, por si, diminui a força do impacto que os elementos de complexidade processual geram com relação ao fator tempo. 
Os motivos relativos à complexidade geram certa mudança do procedimento e na rotina da serventia, alguns ruídos, que de certa forma, causam maior possibilidade de descontrole da gestão, ainda mais se o serviço não estiver bem organizado.

De acordo com a correspondência entre os fatores, efetivo, estrutura física, processos sem complexidade, processos com complexidade no campo processual, estes não demonstram serem as causas preponderantes para o fato do tempo de duração do processo ter sido descumprido, e com grau muito superior à razoabilidade.

Dessa forma, portanto, o descumprimento dos prazos aritméticos e razoáveis do processo não estaria conectado em si ao processo (campo de direito material e processual), e nem à estrutura do serviço, no que concerne ao efetivo (conforme o paradigma previsto em lei), embora possa se relacionar com outros fatores de gestão e organização do serviço não investigados, porém, evidenciados por alguns fatores. Pode se relacionar aos próprios paradigmas legais utilizados como base para o estudo.

De outro modo, pelo menos em parte, a partir da exposição de início, sabendo que o estudo do banco de dados "e-Proc - processos de execução baixados" - gerou conhecimentos atinentes à fase pré-processual e à do processo judicial de conhecimento, até mesmo às de atos iniciais realizados há mais de 10 anos, quando o processo judicial não estava inserido em plataforma eletrônica nem havia a mesma estrutura e organização atual das comarcas, os resultados devem ser vistos com parcimônia.

Orienta-se aguçar os estudos na área de gestão para se tentar desvendar as causas e realizar nova pesquisa que demonstrem os prazos em cada fase processual, relacionados aos processos baixados mais recentes.

De qualquer forma, portanto, pode-se aduzir que o patamar de excesso superior a 100\% dos prazos processuais paradigmáticos, como propalado a partir do gráfico 4 , sem relação com a complexidade do processo, pelo menos não relevante, indica problemas na execução das funções e tarefas executadas, diretamente concernentes aos métodos e processos de gestão, o que vem a evidenciar falta de organização do serviço, no sentido do cumprimento dos fluxos e rotinas procedimentais, ausência de controle de órgão de administração superior, impactando negativa e diretamente os parâmetros da eficiência, e negativa e indiretamente os parâmetros da eficácia e da efetividade, mesmo não sendo exatamente esta a configuração do momento atual. 
Gráfico 05 - Orientação e controle pelos órgãos superiores e inter-relacionados à aplicação das penas alternativas, nas comarcas de menor porte do Estado do Tocantins, a partir das execuções penais baixadas entre os anos 2015 e 2016.

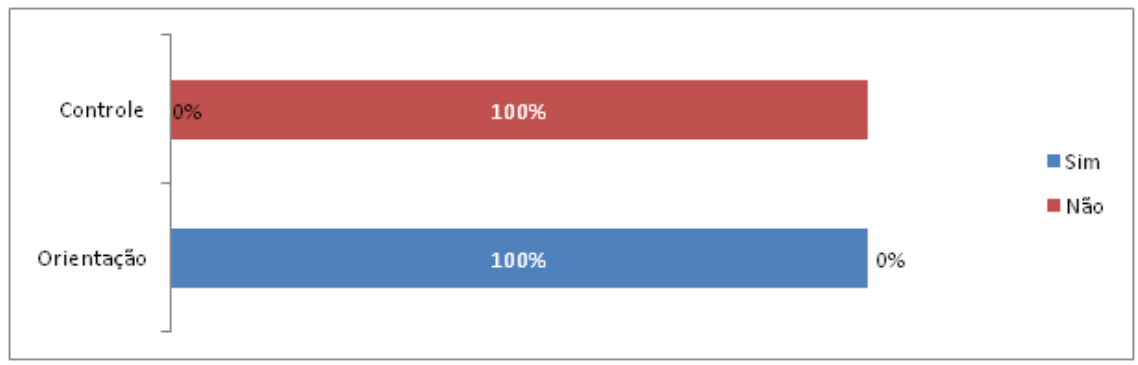

Fonte: Elaborada pelo autor - dados obtidos nas respostas das variáveis 0.1 e 0.2 , pela PresidênciaTJTO, GMFe CGJUS, ano 2017.

Os três órgãos, Presidência do Tribunal de Justiça do Estado, Corregedoria Geral de Justiça (CGJUS) e Grupo de Monitoramento e Fiscalização (GMF) que, segundo o paradigma normativo, têm a incumbência de orientar e efetuar certo grau de controle, no âmbito administrativo, quanto à aplicação das penas alternativas, responderam que sim para a primeira pergunta, relatando que há orientação por parte deles às comarcas. Responderam não para a segunda, informando que não exercem nenhum controle sobre a aplicação das penas alternativas.

Ao se referirem às orientações, a Presidência indicou os seguintes documentos normativos: Resolução n 5, de 2003; Resolução n I, de 2005; Resolução n 16, de 2008; Resolução n 10 , de 2010 ; e a Portaria n 444, de 2012 . A Corregedoria Geral de Justiça informou a Resolução n I, de 2005; a Portaria n 444, de 20 I2; o Provimento n 15, de 2012; e o Provimento $n^{\circ} 12$, de 2012. O Grupo de Monitoramento e Fiscalização, por sua vez, mencionou a Portaria $n^{\circ} 444$, de 2012 ; e a Portaria $n^{\circ}$ I. 5 I 7 , de 2016.

Dos instrumentos que os órgãos superiores informaram para se ter maior padronização (O.। e O.2), há o Provimento n 12, de 20।2, da Corregedoria Geral de Justiça, de 15/8/2012, que instituiu o manual de procedimentos penais no estado do Tocantins. Esta norma detalha os procedimentos das fases de investigação, de processo penal e de execução penal. Portanto, revela-se ser regra de orientação e controle na fase de aplicação da pena. Sua orientação circunscreve-se ao fluxo procedimental. Não intervém na orientação quando da aplicação específica da pena. Não há elementos que detalhem a aplicação da pena alternativa. Não há previsão de estudos prévios do contexto de vida da pessoa processada, de forma interdisciplinar e que possam direcionar para a aplicação da pena alternativa mais adequada, e nem depois de iniciado o processo executivo. 
Segundo as regras paradigmáticas, afetas ao Código de Processo Penal e às normas administrativas citadas, o fato de não haver formas de acompanhamento e controle pelos órgãos reguladores, sobre especialmente os prazos, pode ser fator que impede a melhor organização do serviço, o que pode ter efeitos negativos no que concerne aos parâmetros da eficiência, eficácia e efetividade.

\subsection{Dados referentes à aplicação da pena propriamente dita}

Neste tópico, serão descritas e analisadas a aplicação das penas alternativas, assim categorizadas: i) Sentenças por espécies de veredictos; ii) Sentenças condenatórias; iii) Penas criminais não substituídas; iv) Penas alternativas aplicadas.

\subsection{Classificação das sentenças por espécies de veredictos}

Gráfico 06 - Categorização das sentenças por espécies de veredictos nas Comarcas de menor porte do Estado do Tocantins, referente aos processos baixados em 2015 e 2016.

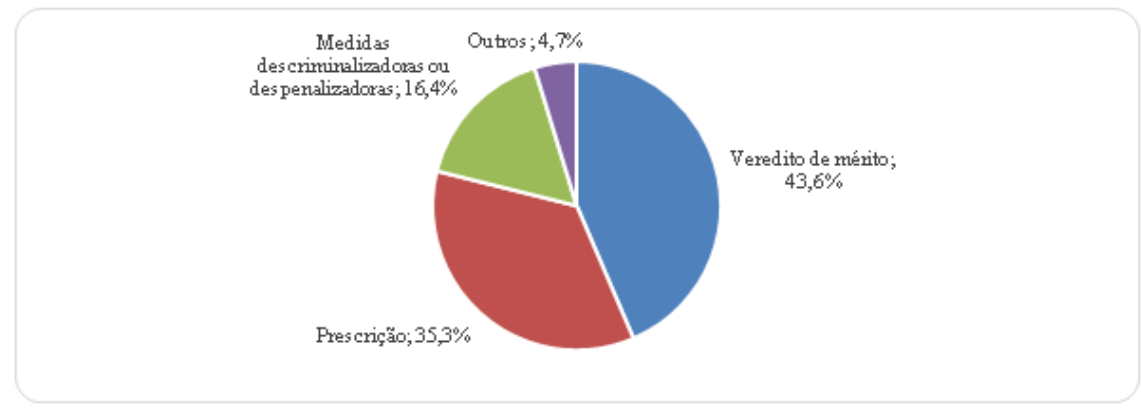

Fonte: Elaborada pelo autor - dados obtidos na tabela EPA. I, extraída do sistema e-Proc TJTO, ano 2017.

gráfico acima foi elaborado, em derivação às tabelas relacionadas à EPA. I (GAGLIARDI, 20 I 8), com o objetivo de fazer visualizar todas as espécies de veredictos, por uma classificação de resultados, mostrando um contexto mais amplo e geral.

Essa classificação afere especialmente o parâmetro atinente à eficácia, pois trata do resultado de qualidade/tempo do produto ou serviço público prestado.

Antes de se realizarem a descrição e a análise dos resultados expostos no gráfico acima, passa-se a uma breve contextualização técnica.

Inicialmente, pode-se conceituar, por sentença, aquela decisão judicial terminativa, proferida durante o decorrer da ação penal, que põe fim a uma fase do procedimento e ao processo de cognição. 
Algumas sentenças anunciam um veredicto de mérito relacionado à decisão sobre o réu ser culpado ou inocente. Esse, aliás, é o principal objetivo do processo penal; excetuada a hipótese relacionada às medidas despenalizadoras, outras espécies de veredictos, já que previstas em lei e dentro de um contexto de política criminal que defende o minimalismo penal.

Noutras, porém, por algum motivo, a conclusão é diversa. Quer-se dizer, ou declaram os veredictos de mérito (como a prescrição, porém, sem declarar se é culpado, ou não) ou apenas extinguem a punibilidade sem a análise de mérito (como, prescrição virtual, morte do réu etc.). Estas sentenças ou demais decisões terminativas nas ações penais, na maioria, não analisaram a conduta típica e a ilicitude do fato descrito como crime.

Para fins deste trabalho, pode-se dizer que o processo penal terá maior grau de eficácia quanto maiores forem os veredictos de mérito referentes à decisão de culpado ou inocente, extraindo-se dos dados aqueles que, por autorização legal, forem condizentes ao caso em concreto à aplicação de medidas despenalizadoras durante o decorrer da ação penal, ou ocorrerem outros motivos, conforme se pode observar do gráfico acima.

Gráfico 07 - Categorização das sentenças por espécies de veredictos, em subgrupos - Comarcas de menor porte do Tocantins, referente aos processos baixados em 2015 e 2016.

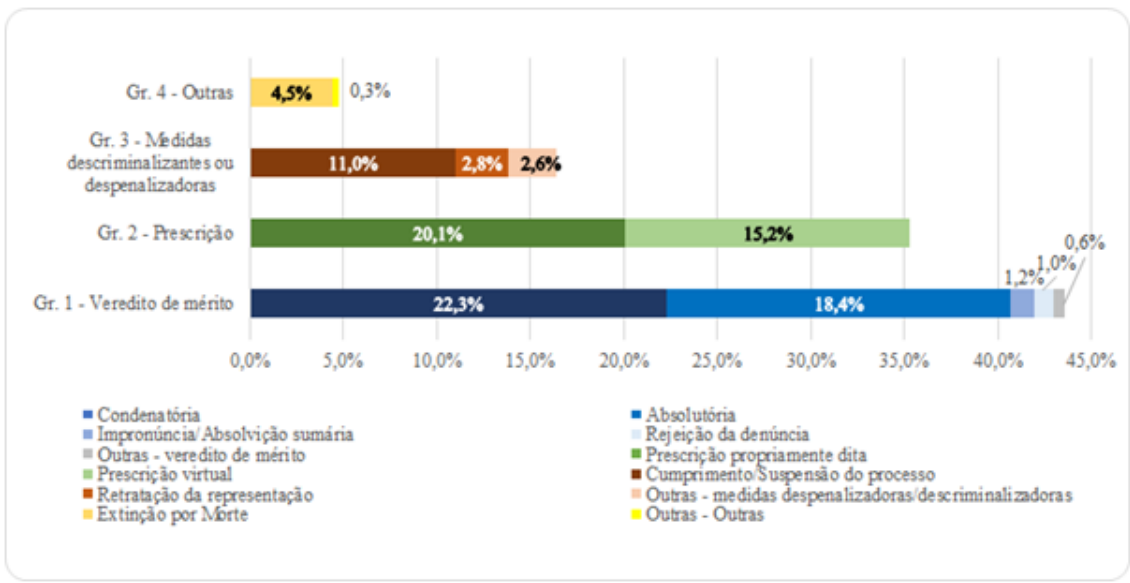

Fonte: Elaborada pelo autor - dados obtidos na tabela EPA. I, extraída do sistema e-Proc TJTO, ano 2017.

Dessa forma, como melhor técnica de visualização, o gráfico partilhou quatro grupos de espécies de sentenças, subdivididos em subgrupos. 
Descrevendo-se os dados, como primeiro grupo está o veredicto de mérito (decisões terminativas em que houve um veredicto sobre ser culpado ou inocente), com índice de 43,6\%, foram considerados os seguintes subgrupos: i) absolutória (7/3 incidências), impronúncia/absolvição sumária (48 incidências), as quais, somadas, geram o índice de 19,6\%; ii) as condenatórias (866 incidências), absolutória e condenatória (I2 incidências), condenatória e impronúncia (uma incidência), e desclassificação e condenação (uma incidência), que resultam o percentual de 22,7\%; iii) de rejeição da denúncia (40 incidências) e trancamento da ação penal por meio de Habeas Corpus (HC) (2 incidências), gerando o índice de I, I\%; e iv) as absolutórias impróprias (8 incidências), com percentual de 0,2\%.

No campo da prescrição (segundo grupo), com índice de 35,3\%, consideraram-se os subgrupos: i) prescrição propriamente dita (773 incidências), absolvição e prescrição (3 incidências), condenação e prescrição (3 incidências), decadência e prescrição ( 1 incidência), gerando percentual de 20,1\%; 2) prescrição virtual (59l incidências), resultando em 15,2\%. As prescrições consideradas virtuais geram sentenças de extinção do processo por falta de interesse de agir.

Das sentenças ou decisões terminativas relacionadas à aplicação de medida descriminalizadora ou despenalizadora (terceiro grupo), o resultado percentual foi de 16,4\%. Subdivide-se em três subgrupos: i) cumprimento de suspensão condicional do processo (428 incidências); ii) renúncia/retratação da representação ( 105 incidências) e desclassificação e retratação da representação (3 incidências); iii) outros, que abrangem: abolitio criminis (3 incidências), transação penal cumprida (38 incidências), composição civil de danos (22 incidências), renúncia da queixa-crime (6 incidências), retratação tácita (5 incidências), perdão do ofendido (2 incidências), perdão judicial (7 incidências), decadência (8 incidências), falta de condição de procedibilidade (5 incidências), perempção (3 incidências), ilegitimidade de parte ( I incidência).

Por fim, o quarto grupo, relacionado às sentenças que, por outros motivos, não se chegou ao veredicto, resultou em 4,7\%. Subdivide-se em dois subgrupos: i) morte do agente ( 173 incidências); ii) outro motivo para o não veredicto, abrangendo: declaração de incompetência ( 9 incidências) e desclassificações ( 2 incidências).

Contextualizando com o paradigma jurídico, pode-se constatar um alto índice de ineficácia do sistema de justiça e do microssistema, tendo em vista o alarmante percentual de desconformidades nos resultados das sentenças por espécies de veredictos, especialmente em duas zonas.

Na primeira zona está o grupo da prescrição (grupo 2) associado ao grupo de veredicto de mérito (grupo I).

Como comparativo, em pesquisa realizada pelo IPEA (20I5, p. 37-38), em municípios dos estados de Alagoas, Distrito Federal, Espírito Santo, Minas Gerais, Pará, Paraná, Rio de Janeiro e São Paulo, com base em amostra de processos baixados em 201 I, restaram índices de sentenças de mérito de 78,7\%, valor bem superior ao verificado nas comarcas de menor porte deste Estado (43,6\%), e um percentual de $8 \%$ 
de prescrição, valor inferior ao deste Estado (35,3\%), porém, consideradas todas as ações penais instauradas durante o período avaliado, até mesmo as hipóteses de aplicação de penas superiores a quatro anos.

Como se analisou em outro trabalho (GAGLIARDI, 2017, p. 227), "os prazos em geral do rito ordinário são de 149 e 215 dias (réu preso ou solto), com a participação da Defensoria Pública [...]. Sem a participação da Defensoria Pública, os prazos no mesmo rito são de 122 e 188 dias, e caso haja complexidade, de 163 e 248 dias." O menor prazo de tempo para se alcançar a prescrição é de pelo menos três anos (BRASIL, CP, art. 109, VI, 1940). Neste tempo, iniciada a ação penal, a partir do recebimento da denúncia, o tempo se renova diante do fenômeno jurídico da interrupção do prazo (BRASIL, CP, art. I I7, I, 1940).

Quer-se dizer que qualquer percentual de prescrição revela a direta violação ao princípio da razoável duração do processo e a ineficácia do sistema de justiça ou a falta do serviço. Revela ainda uma tendência à não continuidade do serviço e da produção de bons resultados, o que faz indiciar para a inefetividade do microssistema. $\bigcirc$ índice de apenas 43,6\% de veredicto de mérito, da mesma forma, demonstra o não cumprimento dos objetivos almejados pela norma, o que atrai para o microssistema a resposta da ineficácia e, por conseguinte, da inefetividade.

Na segunda zona de desconformidade, outro dado que chama a atenção, a partir da classificação de resultado do terceiro grupo (medida descriminalizadora ou despenalizadora), é a quantidade de aplicação de medidas despenalizadoras depois de iniciada a ação penal (especialmente depois do recebimento da denúncia).

Antes, porém, de analisar as hipóteses dessa segunda desconformidade, há as seguintes exceções que as legitimam com base em paradigma normativo, devem, pois, ser observadas: i) os casos de cumprimento da suspensão condicional do processo (BRASIL, LEI No 9.099, art. 89, 1995), que representam 67,3\% das hipóteses do grupo; ii) os casos que envolvem o fato de a vítima de violência doméstica em ação penal pública condicionada à representação ter solicitado a retratação antes da fase do recebimento da denúncia, e, por algum motivo, não ter sido analisada anteriormente. Assevere-se que o art. I 6 da Lei n | I.340, de 2006, exige, caso haja o prévio pedido da vítima, a necessidade de realização de audiência especial para o fim de a suposta vítima renunciar, com a oitiva prévia do Ministério Público ( I I.9\%); iii) os casos de composição civil em ação penal privada (3,5\%), plenamente compatíveis com a Lei porque se coadunam ao perdão tácito (BRASIL, CPP, art. 5I, 1941; CP, art. 106, parágrafo $1^{\circ}$, 1940), e os demais casos circundantes na ação penal privada, o perdão do ofendido $(0,3 \%)$, a decadência $(1,3 \%)$ e a perempção $(0,5 \%)$, relacionados à ação pública condicionada, como a falta de condição de procedibilidade $(0,8 \%)$; iv) casos de transação penal cumprida, depois de desclassificados do crime para delito de menor potencial ofensivo (2,4\%); e v) casos de perdão judicial (0,9\%).

As cinco espécies de casos suspeitos por estarem em desconformidade com a norma são: i) oferecimento e cumprimento da transação penal depois de oferecida a denúncia e até recebida a denúncia, sem ter ocorrido a desclassificação do delito 
incriminador (3,6\% do percentual geral do grupo 3; ii) renúncia ou retratação da representação depois de oferecida a denúncia em delitos em geral, exceto os envolvidos em violência doméstica contra a mulher (4,2\%); iii) renúncia ou retratação da representação depois de recebida a denúncia em delitos envolvendo violência doméstica contra a mulher (0,8\%); iv) renúncia da queixa-crime $(0,9 \%)$; v) retratação tácita em ação penal pública incondicionada envolvendo violência doméstica contra a mulher $(0,8 \%)$.

Verificou-se em alguns casos a aceitação da transação penal mesmo depois de recebida a denúncia, durante a audiência de instrução e julgamento, mesmo sem haver desclassificação de crimes ou outro fundamento legal.

Em algumas das hipóteses houve fundamentação genérica relacionando-se ser a política criminal mais propícia ao caso concreto atinente à violência doméstica contra a mulher, tendo em vista suposta reconciliação do casal, confirmada pela vítima em audiência de instrução e julgamento, porém sem embasamento legal.

Em outras, houve a extinção do processo por renúncia/retratação tácita em caso de não comparecimento da vítima (mulher) em audiência de instrução e julgamento, em caso de suposto crime de lesões corporais e/ou de ameaça e/ou de vias de fato, com elementos de violência doméstica, também sem respaldo legal.

Em outras, surgem em alguns julgados uma nova forma de extinção do processo: retratação da representação tácita da vítima, com base no art. 16 da Lei n ${ }^{\circ}$ | I.340, de 2006, nas situações em que a vítima não comparece em audiência preliminar, também sem respaldo legal e sem observar a condição de vulnerabilidade imposta por lei à mulher, já que esta não realizou pedido prévio.

Em outra situação, depois de receber o inquérito policial, relacionado ao crime envolvendo violência doméstica, o promotor de justiça, em vez de denunciar, remete ao Poder Judiciário, a fim de ser realizada a audiência especial prevista no art. 16 da Lei n ${ }^{\circ}$ I I.340, de 2006. Ocorre que se entende que essa audiência somente poderia ser realizada depois de pedido expresso da vítima, e não como fase obrigatória do procedimento, pois se deve observar a condição de vulnerabilidade legal imposta à mulher.

Por outro giro, em alguns casos, foi possível perceber, quando da coleta dos dados, que há interesse de alguns juízes em pôr fim ao processo de forma mais célere, independentemente das regras dogmáticas formais e materiais. Essa percepção é semelhante à revelada pela pesquisa do IPEA (2015, p. 79), ao detalhar que "profissionais da área de psicossocial da capital dizem que lutam para que o Judiciário se sinta responsável pelo cumprimento das PMAs", e ressaltam diferentes perspectivas das duas áreas: "judiciário trabalha com quantidade, com arquivamento".

Segundo a lei penal, o momento para o oferecimento e cumprimento da transação penal (BRASIL, LEI No 9.099, art. 76, 1995) ocorre, em regra, em procedimento próprio, antes de se instaurar a ação penal. A possibilidade de retratação da representação (BRASIL, CPP, art. 25 e art. 42, I941; CP, art. 102, 1940) pode se dar até antes do oferecimento da denúncia. A possibilidade de retratação (renúncia) da 
representação em crimes de violência doméstica contra a mulher (BRASIL, Lei $\mathrm{n}^{\circ}$ I1.340, art. 16, 2006) pode advir somente até antes do recebimento da denúncia. A circunstância da renúncia ao direito de queixa-crime somente pode ocorrer antes do início da ação penal (BRASIL, CPP, art. 49, 1941 ; CP, art. 104, 1940).

Dessa forma, concluindo o que se denominou de segunda zona de desconformidade, segundo evidenciam os dados, 10,3\% dos processos envolvendo o grupo 3, o que significa I ,7\% do panorama geral, foram extintos por tais motivos, depois de iniciada a ação penal, em discrepância ao previsto em lei. Além de demonstrar ineficácia, por impactar, embora com pouca relevância, o número em geral, demonstra ineficiência por não cumprir as funções e as tarefas padronizadas por lei, e, por conseguinte, não seguir os fluxos e as rotinas procedimentais adotadas.

Restou concreto que essas práticas foram realizadas apenas em algumas comarcas, em estado minoritário. Por isso, aparentemente, aceitando o sistema de justiça (promotor de justiça e juiz) as medidas despenalizadoras em detrimento da lei, depois de iniciada a ação penal, pode haver a violação das regras principiológicas atinentes à necessidade e à suficiência das penas para a reprovação e a prevenção do delito, congruentes com os princípios da proporcionalidade e da igualdade material, e, de certa forma, revelando um efeito que pode ser devastador ao microssistema: a vulgarização na aplicação das penas, sua desproporcionalidade, o que pode gerar maior efeito de desacreditação social e, por outro lado, a defesa do cárcere como a única pena criminal útil e que cumpre seus fins, demonstrando, em última ordem, evidência de inefetividade.

\subsubsection{Classificação das penas aplicadas nas sentenças condenatórias}

Foram analisados os processos penais na fase de conhecimento em que houve sentença condenatória, com base em dois bancos de dados: i) "e-Proc - ações penais baixadas" (882 casos); ii) "e-Proc - processos de execução baixados" (39 I casos).

Os resultados de ambos os bancos de dados foram muito semelhantes, como se verificará abaixo, nos vários gráficos. 
Gráfico 08 - Espécies de penas principais fixadas nas sentenças, nas Comarcas de menor porte do Estado do Tocantins, referentes aos processos baixados em 2015 e 2016.

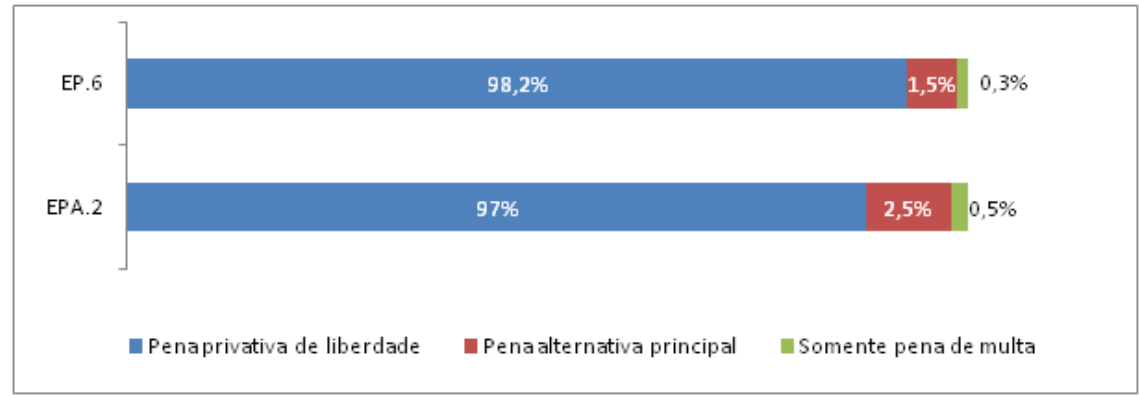

Fonte: Elaborada pelo autor - dados obtidos nas tabelas EPA.2 e EP.6, extraídas do sistema e-Proc, TJTO, ano 2017.

Atinente às sentenças condenatórias, que podem ter relação ao microssistema, da análise do assento de informações "e-Proc - ações penais baixadas", em 97\% das incidências foram aplicadas penas privativas de liberdade; em 2,5\% foram aplicadas penas alternativas principais; e em $0,5 \%$ foi aplicada a pena de multa de maneira solitária.

O banco de dados "e-Proc - processos de execução baixados", em 98,2\% das incidências foram aplicadas penas privativas de liberdade; em I,5\% foram aplicadas penas alternativas principais; e em 0,3\% foi aplicada a pena de multa de maneira solitária.

As penas alternativas denominadas principais, exceção no microssistema, nos dois bancos de dados, relacionam-se em sua totalidade à prática do delito de posse de drogas.

Pode-se asseverar que o número de processos em que se aplica somente pena de multa é ínfimo, o que pode demonstrar que a espécie de pena está caindo em desuso, talvez pela falta de eficácia em sua cobrança.

Com relação às penas privativas de liberdade, importante dado é se estabelecerem os regimes de penas inicialmente fixados, já que nem todas as suas hipóteses configuram encarceramento. 
Gráfico 09 - Regimes de penas privativas de liberdade, nas Comarcas de menor porte do Estado do Tocantins, referentes aos processos baixados em 2015 e 2016.

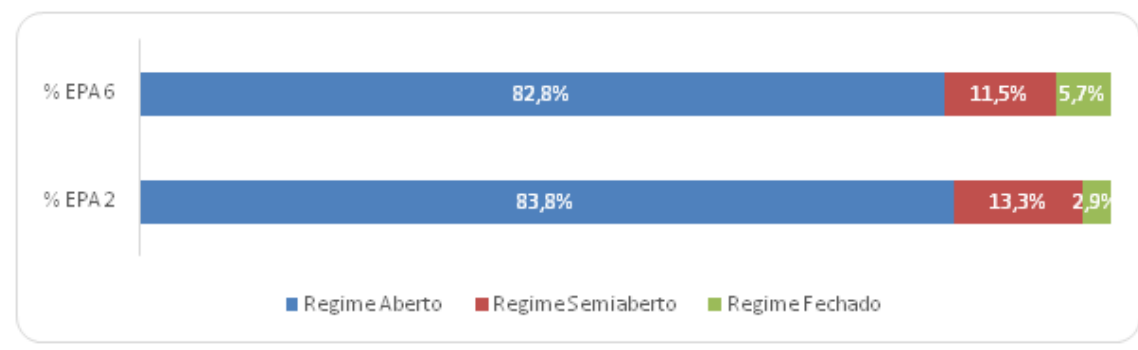

Fonte: Elaborada pelo autor - dados obtidos nas tabelas EPA.2 e EP.6, extraídas do sistema e-Proc TJTO, 2017.

Com relação à substituição para pena alternativa, ou não, e a aplicação de outras medidas ou penas alternativas ao cárcere, do assento de informações "e-Proc - ações penais baixadas" -, demonstrou-se que em 59,4\% das sentenças houve substituição da pena privativa de liberdade para pena alternativa; em 3 I , I \% não houve a substituição, sendo mantida a pena privativa de liberdade; em 6,9\% a pena foi suspensa (sursis penal); em 2,2\% foi aplicada a pena alternativa como pena principal; e em 0,5\% dos casos foi aplicada unicamente a pena de multa.

Do assento de informações "e-Proc - processos de execução baixados" -, demonstrou-se que em 58,8\% das sentenças houve substituição da pena privativa de liberdade para pena alternativa; em 32,7\% não houve a substituição, sendo mantida a pena privativa de liberdade; em 6,6\% a pena foi suspensa (sursis penal); em I,5\% foi aplicada a pena alternativa como pena principal; e em 0,3\% dos casos foi aplicada unicamente a pena de multa.

Essas variáveis demonstram que em aproximadamente 32\% das sentenças condenatórias não houve a substituição para a pena alternativa. É preciso aprofundar o tema para se saber se não está ocorrendo a violação do princípio da preponderância da pena alternativa (GAGLIARDI, 20 I 8, p. 74-76). 
Gráfico I I - Relação das penas substituídas, ou não, e alternativas / regimes de penas, nas Comarcas de menor porte do Estado do Tocantins, referentes aos processos baixados em 2015 e 2016.

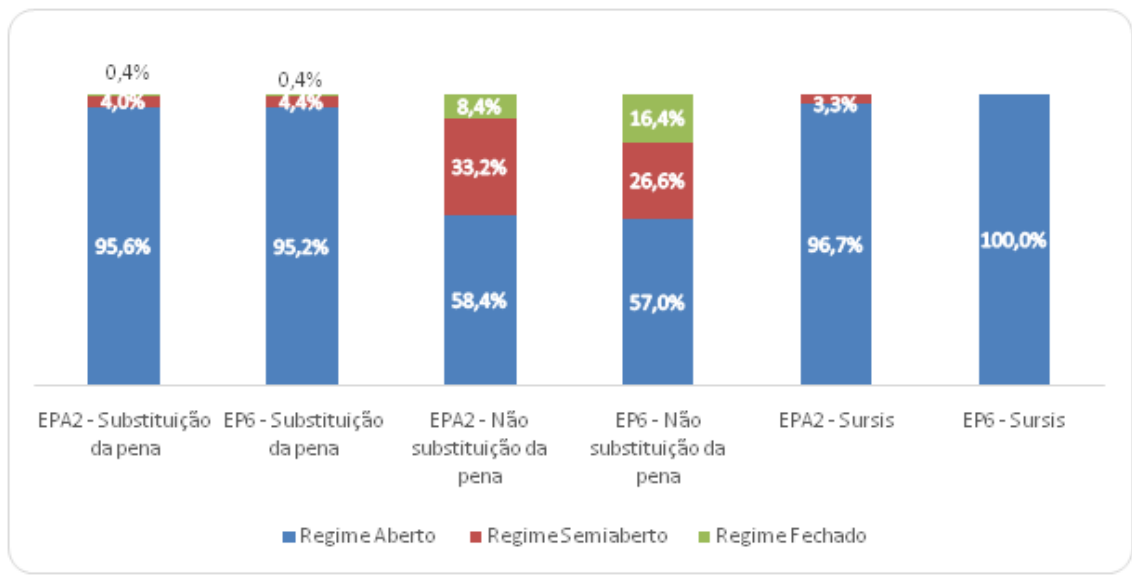

Fonte: Elaborada pelo autor - dados obtidos nas tabelas EPA.2 e EP.6, extraídas do sistema e-Proc TJTO, ano 2017.

Analisando-se os regimes de penas aplicadas de acordo com as substituições para pena alternativa, ou não, e a aplicação de outras medidas ou penas alternativas ao cárcere, relacionado assento de informações "e-Proc - ações penais baixadas" -, das penas substituídas, em 95,6\% o regime aplicado foi o aberto; em 4\% o semiaberto; e em 0,4\% houve a aplicação de regime fechado, não demonstrando relevância, por se aproximar do zero. Das penas não substituídas, em 58,4\% o regime aplicado foi o aberto; em 33,2\% o semiaberto; e em 8,4\% o regime fechado. Das penas suspensas (sursis), em 96,7\% o regime fixado foi o aberto; e em 3,3\% foi fixado o semiaberto. Com relação ao outro assento "e-Proc - processos de execução baixados" -, das penas substituídas, em 95,2\% o regime aplicado foi o aberto; 4,4\% o semiaberto; e 0,4\% no regime fechado. Das penas não substituídas, em 57\% o regime aplicado foi o aberto; em 26,6\% o semiaberto; e em 16,4\% o regime fechado. Das penas suspensas (sursis), em $100 \%$ o regime fixado foi o aberto.

Ambos os bancos de dados demonstram dados semelhantes.

Como no gráfico anterior, que retratou os regimes de penas fixados no geral, em aproximadamente $58 \%$ das penas não substituídas foi aplicado o regime de pena aberto. De outro giro, de modo inverso, em aproximadamente $4 \%$ dos casos houve a aplicação de regimes de penas mais gravosos, mesmo sendo substituída a pena.

Esses dados exigem estudos mais aprofundados para fins diagnósticos, porém, desde logo, caracterizam grau de incompatibilidade da aplicação das normas no processo penal (GAGLIARDI, 20 I 8, p. I5।- | 58; |75-| 8 |). 
Gráfico 12 - Relação entre as penas encarceradoras e não encarceradoras - Comarcas de menor porte do Estado do Tocantins - processos baixados em 2015 e 2016.

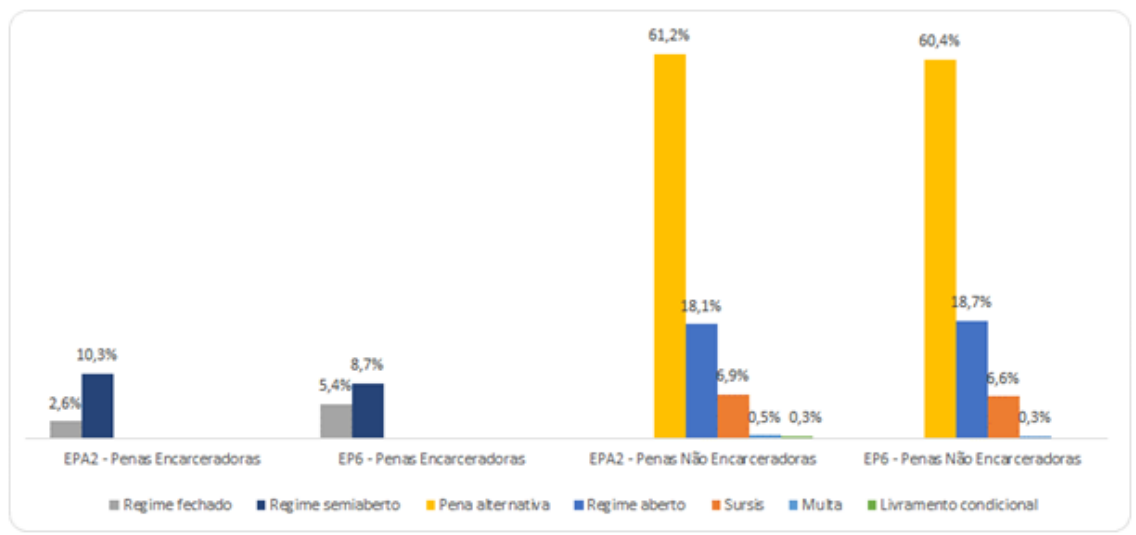

Fonte: Elaborada pelo autor - dados obtidos nas tabelas EPA.2 e EP.6, extraídas do sistema e-Proc TJTO, 2017.

gráfico acima trata da relação das penas não encarceradoras, e de penas encarceradoras.

Antes cabe um comentário. Parte da pena cumprida no regime semiaberto e especialmente a totalidade do aberto não se pode considerar que se trata de encarceramento, dos pontos de vista, pragmático e dogmático. No regime semiaberto, como expôs a pesquisa empírica de Nardo (2017, p. 53-60), considerando as Comarcas de $3^{\text {a }}$ Entrância no Estado do Tocantins, que envolveu a consulta de 2.756 processos, em 2016, do total de 369 pessoas cumprindo pena no regime semiaberto, $48 \%$ dos condenados a cumprem em regime domiciliar por falta de vagas, com a condição de pernoitar em residência e lá permanecer em dias não úteis. $\bigcirc$ regime aberto não se trata de cárcere, ainda se o Estado fosse dotado de estrutura adequada, como as casas do albergado. Todas as pessoas condenadas permanecem em regime flexível, cumprindo meras interdições temporárias de direitos.

Para fins desta pesquisa, não se considerou pena de encarceramento a fixada em regime aberto sem a substituição. Por falta de outros elementos e por se esvair ao objeto deste trabalho, mantém-se o regime semiaberto como meio de encarceramento.

Das penas não encarceradoras, são espécies de acordo com os seguintes grupos: i) penas alternativas, que se subdividem em penas alternativas substitutivas e penas alternativas principais; ii) penas em regime aberto; iii) medidas de suspensão condicional da pena (sursis); iv) pena de multa; e v) pena em livramento condicional. Das penas encarceradoras, dividem-se em regimes fechado e semiaberto.

Passa-se a descrever os dados. A incidência de condenações e aplicações de penas 
criminais ocorreu em 882 casos, atinente ao banco de dados "e-Proc - ações penais baixadas" -; e em 39I casos, no que respeita o banco de dados "e-Proc - processos de execução baixados".

Das penas encarceradoras, relacionado ao assento "e-Proc - ações penais baixadas" ( I 4 incidências) -; em 79,8\% o regime fixado foi o semiaberto; e em 20,2\% o regime foi o fechado. Do banco de dados "e-Proc - processos de execução baixados" (55 incidências) -; em 61,8\% o regime fixado foi o semiaberto; e em 38,2\% o regime foi o fechado.

Analisando-se os números totais das condenações em cada banco de dados, "e-Proc - ações penais baixadas" - e "e-Proc - processos de execução baixados" -, o resultado apresentado pelo gráfico acima demonstra que a representação é de 2,6\% e 5,4\%, respectivamente, no regime fechado; e 10,3\% e 8,7\%, respectivamente, no regime semiaberto. Totalizando as duas hipóteses de penas encarceradoras, os dados concluem que o percentual de penas encarceradoras é de 12,9\% e I4, $1 \%$, respectivamente.

A respeito do banco de dados "e-Proc - ações penais baixadas" -, as penas não encarceradoras representam 87,1\% dos resultados, sendo $61,2 \%$ de incidência de penas alternativas; $18,1 \%$ de regime aberto domiciliar; 6,9\% de sursis; 0,5\% de multa; e $0,3 \%$ de no livramento condicional. Com relação às penas alternativas, são substitutivas $97,2 \%$ e principais 2,8\%.

A respeito do banco de dados "e-Proc - processos de execução baixados" -, as penas não encarceradoras representam 85,9\% dos resultados, sendo 60,4\% de incidência de penas alternativas; $18,7 \%$ de regime aberto domiciliar; 6,6\% de sursis; e $0,3 \%$ de multa. Com relação às penas alternativas, são substitutivas $97,4 \%$ e principais $2,6 \%$.

Gráfico 13 - Comparativo das penas encarceradoras e não encarceradoras entre o sistema penal geral e o microssistema, nas Comarcas de menor porte do Estado do Tocantins, em processos baixados em 2015 e 2016.

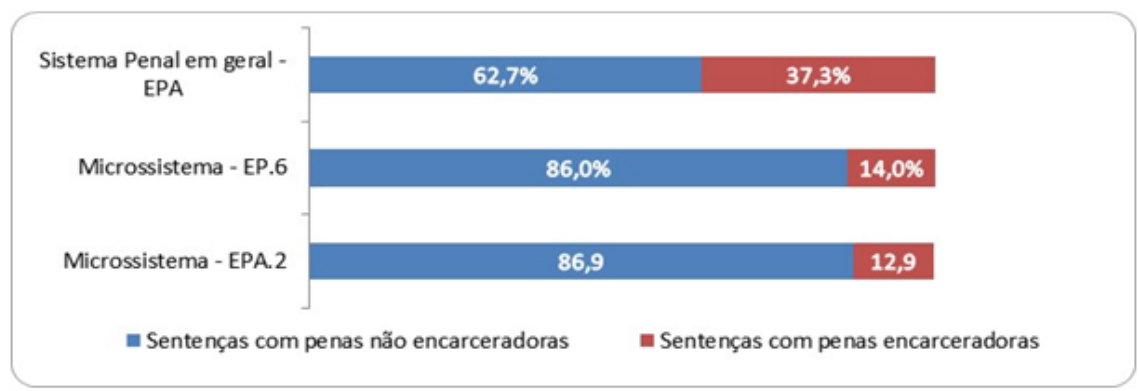

Fonte: Elaborada pelo autor a partir de dados obtidos nas tabelas EPA.2, EP.6 e EPA (exclusões), extraídas do sistema e-Proc TJTO, ano 2017.

É preciso recordar que apenas se apurou, para fins desta pesquisa, a pena aplicada de 
até quatro anos, havendo, ou não, a substituição da pena, ou superior, se houve substituição de pena. Nesse contexto, atinente ao banco de dados "e-Proc - ações penais baixadas" -, foram excluídos 34l processos que se circunscrevem a essas hipóteses. De regra, penas aplicadas em tempo superior a quatro anos são em regime semiaberto ou fechado, portanto, encarceradoras.

Partindo-se de um panorama da situação encarceradora do sistema penal, a fim de se extrair um dado comparativo com o microssistema no referido banco de dados, os números foram somados (total das penas encarceradoras e não encarceradoras do microssistema com o dado excluído), totalizando I .22I sentenças condenatórias.

$\bigcirc$ gráfico acima demonstra que no sistema penal em geral $(37,3 \%)$ o índice encarcerador é superior ao do microssistema ( 12,9\%).

Esses dados demonstram que a maior parte dos processos e das penas aplicadas está dentro do patamar de influência do microssistema e não são encarceradoras.

Demonstram ainda que o fato de haver um microssistema de penas alternativas gera a redução das medidas encarceradoras, diferentemente do que se apontou em outras pesquisas (ILANUD, 2006, p. 254-246).

Esse resultado demonstra que o princípio da preponderância da pena alternativa (GAGLIARDI, 20 I 8, p. 74), pelo menos em parte, está sendo atendida.

\subsubsection{Classificação das penas não substituídas}

Gráfico 14 - Quantidade de motivos para a não substituição da pena, nas Comarcas de menor porte do Estado do Tocantins, em processos baixados em 20 I 5 e 2016.

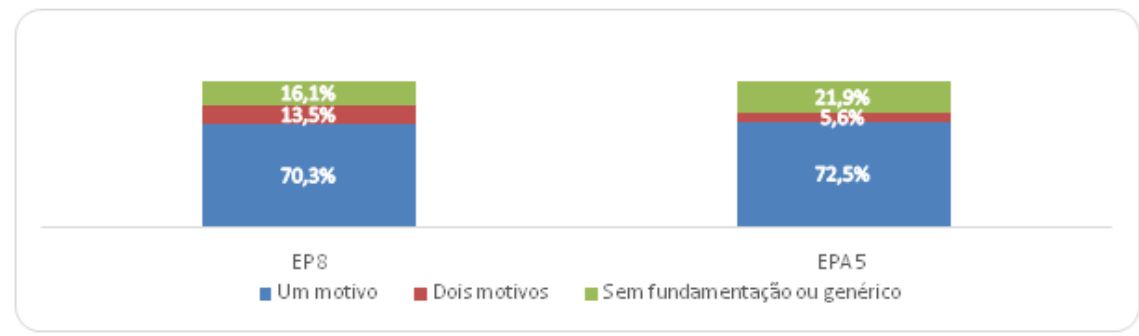

Fonte: Elaborada pelo autor a partir de dados obtidos nas tabelas EPA.5 e EP.8, extraídas do sistema e-Proc TJTO, ano 2017.

Os dados acima demonstram que a maior parte das hipóteses para a não substituição da pena privativa de liberdade para pena alternativa decorreu de apenas um motivo. Em apenas $14 \%$ e $6 \%$ dos casos, respectivamente aos bancos de dados "e-Proc - ações penais baixadas" - e "e-Proc - processos de execução baixados" -, houve dois. Não houve nenhuma hipótese de um terceiro ou quarto motivo para a não substituição.

Em 16\% e 22\% das hipóteses, respectivamente, não houve fundamentação legal ou 
esta se apresentou como genérica. Segundo a percepção durante a coleta dos dados, isso não vem a significar que o juiz simplesmente não substituiu a pena, por seu arbítrio, e sim apenas pelo fato de não anotar nenhum fundamento no momento da aplicação da pena.

Gráfico 15 - Motivos para a não substituição da pena, nas Comarcas de menor porte do Estado do Tocantins, em processos baixados em 2015 e 2016.

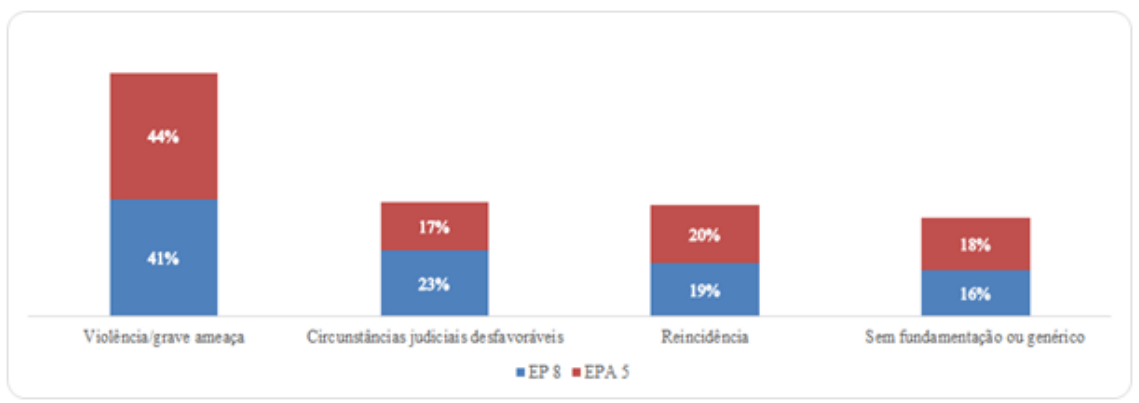

Fonte: Elaborada pelo autor a partir de dados obtidos nas tabelas EPA.3 e EP.I I, extraídas do sistema e-Proc TJTO, 2017.

Os motivos técnicos para os juízes não substituírem a pena privativa de liberdade para pena alternativa foram, na sequência, da maior incidência para a menor: violência ou grave ameaça contra pessoa (44\% - considerando "e-Proc - ações penais baixadas" -; e 41 \% - "e-Proc - processos de execução baixados"); não suficiência, com base nas circunstâncias judiciais negativas ( $17 \%$ - considerando "e-Proc - ações penais baixadas" -; e 23\% - "e-Proc - processos de execução baixados"); reincidência (20\% considerando "e-Proc - ações penais baixadas" -; e 19\% - "e-Proc - processos de execução baixados"); sem fundamentação e com fundamentos genéricos (18\% considerando "e-Proc - ações penais baixadas" -; e 16\% - "e-Proc - processos de execução baixados").

Outros casos (não inseridos no gráfico) incluem os vinculados à profissão do réu ou local de moradia distante ( I ,4\% - considerando "e-Proc - ações penais baixadas" -; e I,7\% - "e-Proc - processos de execução baixados"); e por entender haver proibição legal - crimes, hediondos ou de tráfico de drogas ( I,6\% - considerando "e-Proc-ações penais baixadas" -; e I,7\% - "e-Proc-processos de execução baixados").

Ambos os bancos de dados, mais uma vez apresentam dados correlatos.

Segundo a norma legal, e conforme precedentes, as decisões judiciais exigem fundamentação e ainda de forma concreta, relacionada aos fatos e à comprovação deles. Mesmo que se adote a teoria da discricionariedade judicial, o que se revela um equívoco 
(GAGLIARDI, 20 |8, p. |8|- | 86), esta deve ser adstrita à lei, senão, seria hipótese de arbitrariedade.

Além das causas previstas em lei, não se demonstra lícito impedir a substituição para a pena alternativa diante do crime a que foi condenado. Foram declarados inconstitucionais os dispositivos legais relacionados aos crimes hediondos e à lei de drogas.

Não há, no mesmo sentido, impedimento legal para a substituição de pena, na hipótese de a pessoa condenada possuir um trabalho distante da sede da comarca ou que exija constantes viagens, ou diante do local de moradia, como os casos de trabalhadores da zona rural e dos caminhoneiros, pelo contrário. Há várias possibilidades legais de penas alternativas, devendo haver um ajuste entre as condições pessoais do condenado e as características das penas e das entidades componentes da rede social (BRASIL, Lei $n^{\circ} 7.210$, art. 148, 1984). Embora tais hipóteses tenham gerado número irrelevante, diante da pouca incidência, sobressaem-se importantes para fins didáticos.

Portanto, pode-se sustentar que, pelo menos, 20,7\% (considerando "e-Proc ações penais baixadas"); e 16,5\% ("e-Proc - processos de execução baixados") das hipóteses para a não substituição de pena ocorreram de maneira arbitrária e contrária aos princípios jurídicos que regem o microssistema, o que demonstra evidências de ineficiência no que concerne às funções e tarefas executadas, já que não se observou a rotina procedimental prevista conforme o paradigma legal.

\subsubsection{Classificação das penas alternativas aplicadas}

Gráfico 16 - Penas alternativas aplicadas nas sentenças condenatórias (em conjunto), nas Comarcas de menor porte do Estado do Tocantins, em processos baixados em 2015 e 2016.

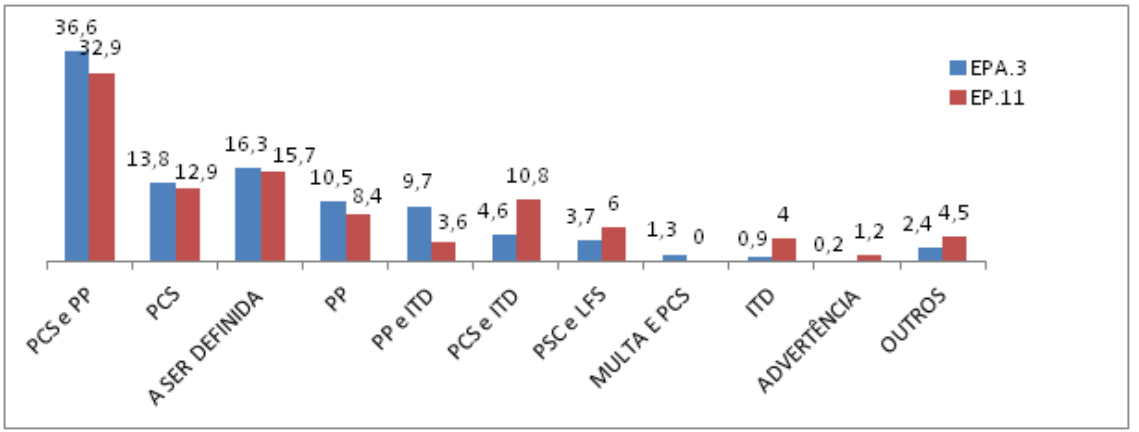

Fonte: Elaborada pelo autor a partir de dados obtidos nas tabelas EPA.3 e EP. I I, extraídas do sistema e-Proc TJTO, 2017.

Acima dois bancos de dados, "e-Proc - ações penais baixadas" -, e "e-Proc - 
processos de execução baixados" -, por meio das tabelas EPA.3 e EP. I I , são descritas e comparadas, no que concerne às espécies de penas alternativas aplicadas na condenação de cada réu, independentemente do número de crimes a que foi condenado.

Com relação ao primeiro banco de dados, dos 535 processos em que a pena foi substituída para pena alternativa e foi aplicada a pena alternativa como pena principal, conforme os resultados da EPA.3, a mais aplicada; mais de um terço das hipóteses foi prestação de serviços em conjunto com a prestação pecuniária (36,6\%). Na sequência, houve os seguintes índices: a ser definida pelo juízo da execução (16,3\%), somente prestação de serviços $(13,8 \%)$, somente prestação pecuniária $(10,5 \%)$, prestação pecuniária e interdição temporária de direitos (9,7\%), prestação de serviço e interdição temporária de direitos (4,6\%), prestação de serviços e limitação de fim de semana (3,7\%), multa e prestação de serviços (1,3\%), somente interdição temporária de direitos $(0,9 \%)$, prestação pecuniária e limitação de fim de semana $(0,6 \%)$, curso educativo $(0,6 \%)$, limitação de fim de semana $(0,2 \%)$, advertência $(0,2 \%)$, e advertência e prestação de serviços (0,2\%), prestação de serviço e comparecimento em entidade para tratamento $(0,2 \%)$.

Descrevendo o segundo banco de dados, dos 249 processos em que a pena foi substituída para pena alternativa e foi aplicada a pena alternativa como pena principal, conforme os resultados da EP. I I, a mais aplicada, mais de um terço das hipóteses foi prestação de serviços em conjunto com a prestação pecuniária (32,9\%). Na sequência, houve os seguintes índices: a ser definida pelo juízo da execução (I 5,7\%), somente prestação de serviços ( $12,9 \%)$, prestação de serviço e interdição temporária de direitos ( $10,8 \%)$, somente prestação pecuniária $(8,4 \%)$, prestação de serviços e limitação de fim de semana (6\%), somente interdição temporária de direitos (4\%), prestação pecuniária e interdição temporária de direitos (3,6\%), advertência (1,2\%), limitação de fim de semana $(0,8 \%)$, prestação de serviços e prestação inominada $(0,8 \%)$, prestação pecuniária e prestação de serviços e interdição temporária de direitos $(0,8 \%)$, prestação pecuniária e limitação de fim de semana $(0,4 \%)$, interdição temporária de direitos e limitação de fim de semana (0,4\%), curso educativo e comparecimento em entidade para tratamento $(0,4 \%)$, multa e prestação de serviços e interdição temporária de direitos $(0,4 \%)$, prestação pecuniária e prestação inominada $(0,4 \%)$. 
Gráfico 17 - Penas alternativas aplicadas nas sentenças condenatórias (incidência individual), nas Comarcas de menor porte do Estado do Tocantins, em processos baixados em 2015 e 2016

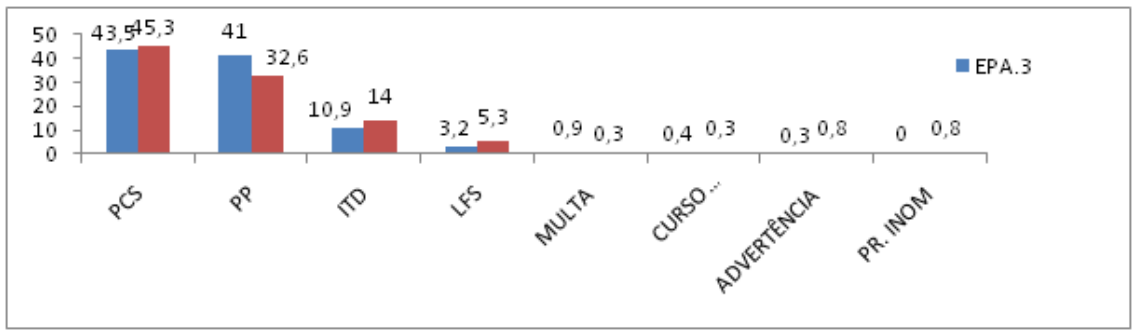

Fonte: Elaborada pelo autor - dados obtidos nas tabelas EPA.3 e EP. I I, extraídas do sistema eProc TJTO, 2017.

Somando-se todas as penas alternativas aplicadas, independentemente de ter sido aplicada isoladamente, ou não, em ambos os bancos de dados, "e-Proc - ações penais baixadas" - (EPA.3) e "e-Proc - processos de execução baixados" - (EP.I I), respectivamente, em um total de 540 e 236 penas alternativas aplicadas, a pena de prestação de serviços teve a incidência em 43,5\% e 45,3\%, a pena de prestação pecuniária em 41\% e 32,6\%, a interdição temporária de direitos em 10,9\% e 14\%, respectivamente, a limitação de fim de semana em 3,2\% e 5,3\%. Os demais casos demonstram terem sido irrelevantes, circunscrevendo a multa substitutiva $(0,9 \%$ e 0,3\%, respectivamente), curso educativo (0,4\% e 0,3\%), advertência (0,3\% e 0,8\%, respectivamente). No último banco de dados houve ainda $0,8 \%$ das incidências em prestação inominada, na forma de cestas básicas.

Esses resultados divergem da pesquisa realizada na cidade de São Paulo, em duas Varas Criminais, após a edição da lei específica em 1998, mas antes de 2002, por Cardoso (apud SICA, 2002, p. I84- 185), no sentido de ter demonstrado a aplicação da pena de prestação pecuniária em apenas $5 \%$ dos casos passíveis de substituição. De outro modo, o resultado compatibiliza-se com a pesquisa realizada pelo Instituto Latino Americano das Nações Unidas (ILANUD) em 2006, que destacou as penas com mais incidência a prestação de serviços e em sequência a prestação pecuniária (ILANUD, 2006, p. 258), e também com a pesquisa produzida pelo IPEA(20 I 5, p. 82).

Evidencia-se um número não tão expressivo da pena de prestação de serviços, tendo em vista sua importância integradora, embora tenha sido a espécie de pena alternativa mais aplicada. Outra pena alternativa com tal função é a que tem conteúdo educativo. No entanto, o resultado de penas ligadas ao estudo ou profissionalização, atinentes à limitação de fim de semana ou às hipóteses de medidas educativas relacionadas aos crimes envolvendo drogas ilícitas, foram ínfimas. As hipóteses de encaminhamento para estudo ou treinamento de alguma técnica foram isoladas, o que evidencia que o microssistema não tem se voltado à meta da inclusão social. 
E mesmo nas hipóteses em que foi aplicada a denominada limitação de fim de semana, sua operacionalização se deu apenas no sentido de permanência da pessoa em sua residência em alguns horários durante o fim de semana. Não houve o encaminhamento para Casa do Albergado, pois, como se asseverou, não é existente nem se encaminhou a outra entidade, tampouco para a realização de cursos educativos.

Sugere-se que os motivos para a não aplicação de algumas penas alternativas ocorreram pela falta de estrutura para orientação, acompanhamento e fiscalização, e talvez pela falta de uma rotina procedimental. Sugere-se que não haja a exclusão da prestação pecuniária como pena alternativa, como se pretende com o Projeto de Lei $n^{\circ}$ 3.473, de 2000 (BRASIL, Câmara dos Deputados, 2000), tendo em vista sua alta incidência (segunda espécie de pena mais aplicada), e, portanto, por seus adjetivos de melhor operacionalização e governança da administração da justiça, e compatibilização com os interesses e possibilidade do reeducando.

No mesmo sentido da conclusão da pesquisa realizada pelo IPEA, além das penas alternativas já previstas, outras poderiam ser criadas, "tal como as já previstas, preservem a dignidade e a integração social do apenado, sirvam para reafirmar a proibição da conduta social tipificada como crime, imponha uma sanção negativa ao apenado e colabore para seu aprendizado" (IPEA, 20 I 5, 9I). Quanto mais forem os instrumentos à disposição da justiça, mais possibilidades haverá em favor da aplicação da pena alternativa.

Gráfico 18 - Tempo da condenação / crimes com penas substituídas, nas Comarcas de menor porte do Estado do Tocantins, em processos baixados em 2015 e 2016.

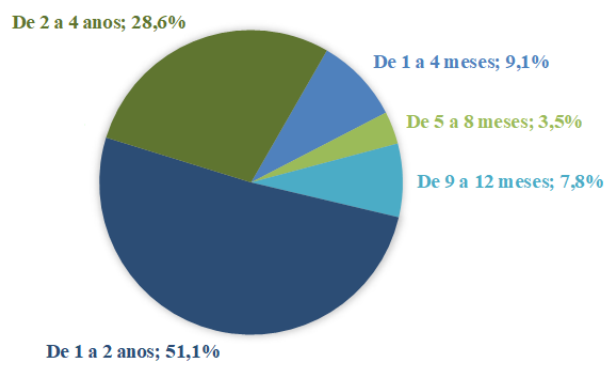

Fonte: Elaborada pelo autor a partir de dados obtidos na tabela EP. I 0, extraída do sistema e-Proc TJTO, 2017.

gráfico acima representa a quantidade de pena privativa de liberdade fixada na sentença. Pode-se perceber que, em todos os casos em que houve a substituição à pena alternativa, a pena máxima fixada foi de até quatro anos, plenamente alinhada à regra prevista no art. 44, I, do Código Penal. 
A maior parte dos casos está circundando entre a pena fixada superior a um e até dois anos (51\%). Tem grande relevância por atingir quase um terço das hipóteses, as penas fixadas superiores a dois e até quatro anos (28,6\%). As penas fixadas em até um ano representam aproximadamente $20 \%$ dos casos.

Gráfico 19 - Classificação do tempo da pena de prestação de serviços fixada na sentença, nas Comarcas de menor porte do Estado do Tocantins, em execuções penais baixadas em 2015 e 2016.

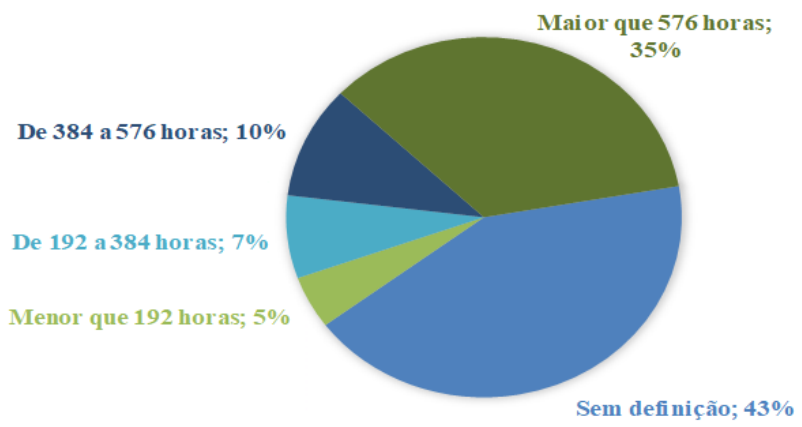

Fonte: Elaborada pelo autor - dados obtidos nas tabelas EP. I3, extraídas do sistema e-Proc TJTO, 2017.

gráfico acima representa a quantidade de tempo de prestação de serviços à comunidade ou à entidade pública fixada na sentença. Na maior parte das hipóteses não houve a definição do tempo pelo juiz (43\%), o que de certa forma pode evidenciar mais insegurança dos juízes na delimitação de seus valores.

Dos casos em que o tempo foi fixado e definido na sentença, constata-se que, em $35 \%$ deles, a pena tem um tempo superior a 576 horas; e I 2\% representam penas fixadas em até 365 horas.

A regra determina a aplicação da referida pena alternativa no mesmo tempo da pena privativa de liberdade fixada. $\bigcirc$ sistema adotado é o de horas-tarefa. Leva-se em consideração para se calcular o tempo de prestação de serviço, a razão de uma hora de tarefa por dia de condenação (BRASIL, CP, art. 46, parágrafo 3, 1940). Nesse sentido, o cálculo mais acertado é o de verificar a quantidade de dias da pena privativa de liberdade e depois transformar em horas-tarefa (GOMES, 2007, p. 807).

Comparando-se os resultados do gráfico 22 (EP. I 0) e os resultados no gráfico acima (EP. I 3), de forma proporcional, pode-se verificar que naquela variável cerca $20 \%$ das penas privativas de liberdade foi fixada em até um ano; $51 \%$ das penas privativas de liberdade foram superiores a um ano e até dois anos; e 29\% dela superior a dois e inferior a quatro anos. Traduzindo em horas, conforme a regra legal, de uma pena de até um ano, a pena de prestação de serviços seria de até 365 horas. De até dois anos, uma pena de 730 horas. 
Dessa forma, apresenta-se o gráfico abaixo.

Gráfico 20 - Relação entre a pena privativa de liberdade e a pena de prestação de serviços, fixadas na sentença, nas Comarcas de menor porte do Estado do Tocantins, em execuções penais baixadas em 2015 e 2016.

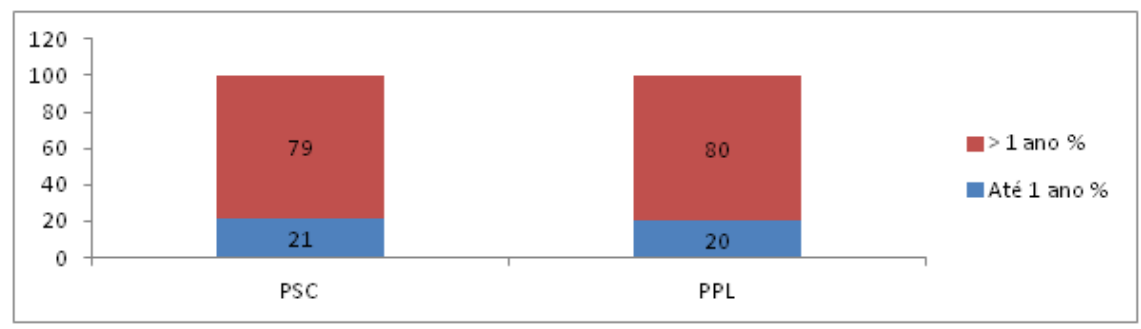

Fonte: Elaborada pelo autor - dados obtidos nas tabelas EP. 10 e EP. I 3, extraídas do sistema e-Proc TJTO, 2017.

Este gráfico representa a aparente compatibilidade entre a pena privativa de liberdade aplicada e a pena de prestação de serviços, que seguem o mesmo paradigma de tempo de duração. Foi fixada cerca de $20 \%$ das penas privativas de liberdade em até um ano, e em semelhante patamar de penas de prestação de serviços, conforme o número total de sua fixação em horas na sentença.

Gráfico 21 - Classificação do valor da pena de prestação pecuniária fixada na sentença, nas Comarcas de menor porte do Tocantins, em execuuções penais baixadas em 20 I 5 e 2016.

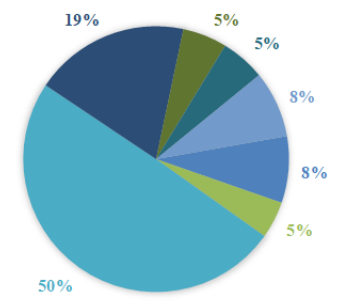

- Sem definição

- Até $1 / 2$ Salário Minimo

- Mai or que $1 / 2$ a 1 Salário Minimo

- Maior que 1 a 2 Salários Minimos

- Maior que 2 a 3 Salários Minimos

- Maior que 3 a 4 Salários Minimos

- Mai or que 4 Salários Minimos

Fonte: Elaborada pelo autor a partir de dados obtidos na tabela EP. I2, extraída do sistema e-Proc TJTO, 2017. 
O gráfico acima representa a quantidade em valores da pena de prestação pecuniária fixada na sentença.

Diferentemente da hipótese da prestação de serviços, somente em $8 \%$ dos casos não houve a definição pelo juiz, o que aparentemente demonstra mais segurança dos juízes na definição dos valores desta pena em sentença.

Em mais da metade das hipóteses (55\%), a pena foi fixada em até um salário mínimo, o que de certa forma demonstra a incompatibilidade da lei com a aplicação da pena no caso concreto, seja porque alguns valores estão abaixo do mínimo legal, seja porque a maior parte delas foi fixada no mínimo legal. $\bigcirc$ mínimo fixado pela lei é de um salário mínimo e o máximo de 360 salários mínimos e há muitos dos casos em que o tempo da pena fixada foi superior ao mínimo legal.

De outra banda, em 38\% das hipóteses houve a aplicação da pena pecuniária acima do mínimo legal. Destes, $8 \%$ dos casos ultrapassam a quatro salários mínimos.

Há evidências de que parte dos juízes não se baseia na proporcionalidade entre a pena privativa de liberdade fixada na sentença e o valor mínimo e máximo da pena pecuniária, o que de certa forma merece mais reflexão dos juízes.

Esses resultados equiparam-se aos produzidos pela pesquisa empírica realizada por Cardoso (apud SICA, 2002, p. 184-185). Naquele estudo, concluiu-se que a maior parte das penas pecuniárias foi de um salário-mínimo. Segundo o autor, isso pode significar que o principal elemento de valoração é a capacidade econômica da pessoa condenada, o que de certa forma pode caracterizar desproporcionalidade, o que seria uma forma de banalização do microssistema, como asseveram Nucci (2008, 4l7) e Reale Júnior (2013, p. 384). Essa é a mesma conclusão de alguns juízes entrevistados em pesquisa realizada pelo IPEA (2015, p. 59) ao esclarecerem que "um dos motivos alegados por vários juízes para o desprestígio das penas alternativas foi a banalização de sua aplicação pela oferta de cestas básicas no passado".

Mas pode significar também que a maior parte das penas privativas de liberdade foi aplicada no mínimo legal e, ao contrário da conclusão anterior, não se baseou na capacidade econômica do réu, e se tal ocorreu, deu-se por mera presunção, a fim de não realizar a elevação do valor. Certo é que a maior parte dos réus apresentou-se na pesquisa com pouca capacidade econômica, como se pode verificar com os resultados do infográfico I (EP.4), que tratou da profissão dos réus. Descreveu-se que 8,5\% são desempregados e 55,2\% desempenham atividades sem valor econômico agregado e de menor técnica intelectual, sem ou com pouca qualificação.

Propõe-se, dependendo da situação econômica do réu, a pena pecuniária, depois de aplicada a devida regra de proporcionalidade, que poderia ser agravada ou minimizada, conforme a possibilidade econômica e os critérios da reprovação e da prevenção, mas sempre nos limites máximos e mínimos.

Ou seja, o valor deve variar entre I e 360 (trezentos e sessenta) salários mínimos nacionais (BRASIL, CP, art. 45, parágrafo ${ }^{\circ}$, 1940). Depois, para evitar a desproporção e a violação do princípio da suficiência da pena alternativa que poderia ser causada diante dos extremos dos valores fixados em lei, privilegiando também nesse momento a 
capacidade econômica do condenado, como tem decidido a jurisprudência dos Tribunais superiores ao se utilizarem da analogia para com o sistema da valoração da pena de multa, uma solução seria aplicar o redutor de até um trigésimo ou o intensificador da pena em até cinco vezes, conforme previsto em situação analógica no art. 49, parágrafo $1^{\circ}$, do Código Penal. Para apenação dos crimes de maior gravidade ou denominados de "colarinho branco", uma solução jurídica viável seria aplicar sobre o valor fixado a elevação do valor até o triplo, caso se mostre ineficaz à reprovação e à prevenção do delito; e no art. 60, parágrafo $1^{\circ}$, do Código Penal. $\bigcirc$ valor deve estar adstrito ao interior desses patamares legais, não podendo ser inferior ao mínimo mesmo em hipótese de tentativa ou da diminuta condição econômica da pessoa condenada (GOMES, 2007, p. 800; MIRABETE, 2002, p. 56 I; CAPEZ, 20।4, p. 444).

Com base nas respostas do gráfico seguinte (EP. 16 e EP. I7), que tratou da aplicação, ou não, de hipóteses de ressarcimento de danos à vítima, pode-se vislumbrar a irrelevância dos resultados acerca do direcionamento da prestação pecuniária à vítima. $\bigcirc$ resultado foi de apenas 5 casos que representam aproximadamente $2 \%$, mesmo envolvendo $65 \%$ das hipóteses do todo pesquisado em que havia crimes com vítimas concretas.

Essa é uma evidência de que a vítima ainda é pouco privilegiada no sistema penal, e especialmente no microssistema, como se pode verificar com maior abrangência no gráfico abaixo.

Gráfico 22 - Medidas de ressarcimento à vítima / vítimas concretas, ou não, nas Comarcas de menor porte do Estado do Tocantins, em execuções penais baixadas em 2015 e 2016.

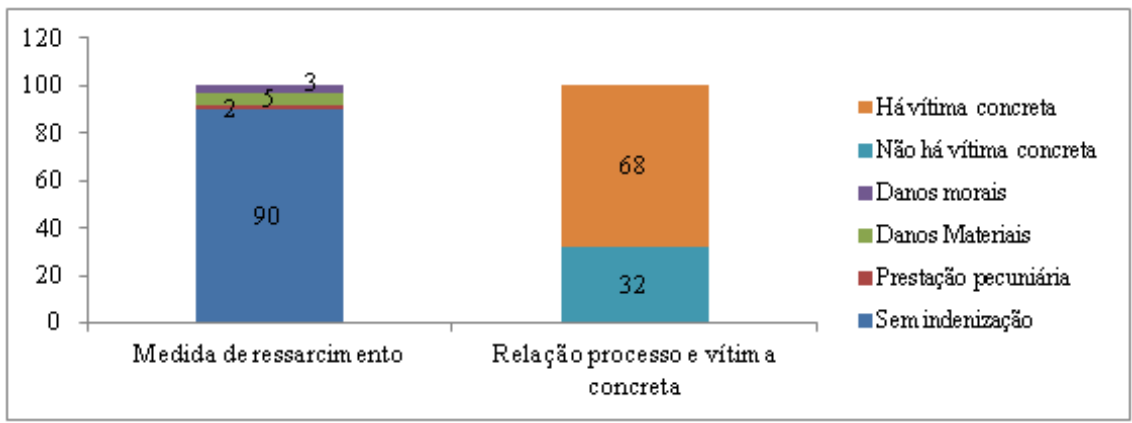

Fonte: Elaborada pelo autor - dados obtidos nas tabelas EP. 16 e EP. I 7, extraídas do sistema e-Proc TJTO, 2017

Os resultados acima demonstram que $90 \%$ dos processos em que foi aplicada pena alternativa não houve o ressarcimento de danos à vítima. Destes, 68\% havia vítimas concretas; e em 32\% a vítima era abstrata, como a coletividade. 
Em apenas 10\% houve a aplicação por meio da sentença condenatória de medidas de ressarcimento à vítima. $2 \%$ das hipóteses representam a prestação pecuniária, uma das penas alternativas previstas em lei, como já se mencionou. 5\% referem-se à indenização por danos materiais e $3 \%$ à indenização por danos morais.

Durante a coleta de dados, verificou-se que a maior parte dos juízes não decide sobre a indenização prevista no art. 387, IV, do CPP. Resume-se em três situações: I) Não se trata do assunto nem se menciona (maioria dos casos); 2) Outros argumentam sobre o não cabimento, mas não fundamentam; e 3) Outros argumentam sobre o não cabimento, sob os seguintes fundamentos: 3. I) Não há pedido do MP na inicial - critério processual - princípios da congruência, do contraditório e da ampla defesa (posição majoritária na jurisprudência do Tribunal de Justiça local); 3.2) Não há parâmetros / elementos mínimos e suficientes para a fixação da indenização; 3.3) Deve ser analisada em processo cível; 3.4) Inexistência de prejuízo objetivo; 3.5) Os bens subtraídos foram restituídos; 3.6) Não houve dano material.

Alguns juízes que aplicaram a condenação na forma de indenização mínima à vítima fundamentaram que se trata de norma cogente e independe de pedido do MP, o que de certa forma compatibiliza-se ao espírito da lei, já que esta determinou ao juiz fixar o valor mínimo para a reparação de danos causados pela infração, mas não alterou o art. 4l do mesmo regramento processual, incluindo norma correlata, que trata dos elementos essenciais da denúncia.

Um detalhe importante da leitura dos resultados deve ser observado, embora com parcimônia. Não é porque a maior parte das respostas envolve vítimas concretas (68\%) e porque está indicado o não ressarcimento ou pagamento de indenização da maior parte delas (90\%), que no caso concreto caberia indenização. Porém, em tese, crimes, ao mínimo, geram danos morais à vítima, por presunção "in re ipsa", de forma assemelhada à restrição indevida do nome do consumidor. Além disso, como se asseverou, a maior parte dos casos, nem avaliação expressa acerca se caberia. $\bigcirc$ direito há nos autos dos processos avaliados, o que se pressupõe, baseado em outros fundamentos judiciais, acima descritos, de que não há pedido inicial ou elementos mínimos e suficientes para a fixação da indenização.

A vantagem da aplicação da indenização justa à vítima no processo penal é desburocratizar o serviço, reduzir as demandas judiciais e reparar os danos efetivamente à vítima, que em muitas situações encontra-se acuada e sem forças para reagir ou até não tem o acesso à informação para agir, ou não tem o acesso à justiça. Muitas vezes não se espera que a vítima vá processar seu agressor.

Para tal, da mesma forma que se alterou o disposto no art. 387, IV, do CPP (BRASIL, 194I) pela Lei n I I.719, de 2008, uma solução seria se alterar o art. 4I do CPP, para incluir o necessário pedido de ressarcimento nas hipóteses em que há vítima concreta e há danos. Isso especialmente porque a jurisprudência e as decisões judiciais de primeiro grau não têm reconhecido tal instituto como direito cogente, imposto por lei. 
Gráfico 23 - Quantidade de penas de interdição de direito aplicadas em um mesmo caso, nas Comarcas de menor porte do Estado do Tocantins, em execuções penais baixadas em 2015 e 2016

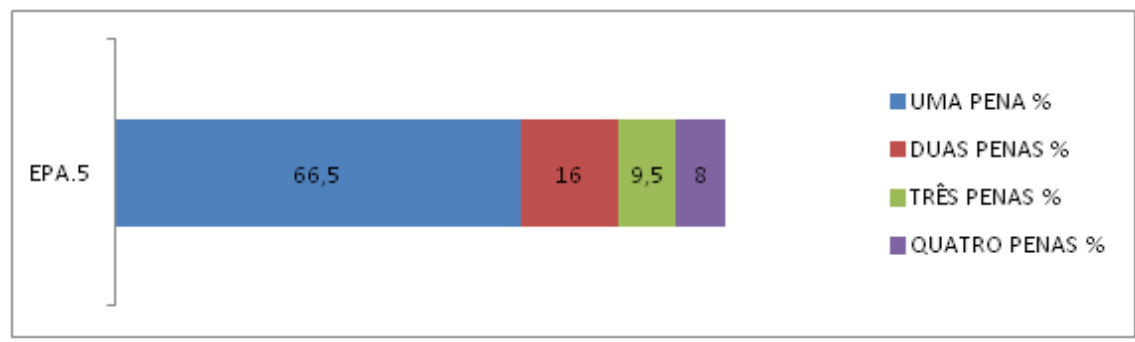

Fonte: Elaborada pelo autor a partir de dados obtidos na tabela EP I 4, extraída do sistema e-Proc TJTO, 2017.

O gráfico acima descreve a quantidade de penas de interdição de direitos aplicadas a um réu em um mesmo processo. 66,5\% dos casos (42 incidências) representam que houve uma pena de interdição de direito. $16 \%$ ( 10 casos) informam que houve duas penas. 9,5\% (6 incidências) determinam que houve três penas; por fim, em 8\% aplicouse quatro penas de interdição de direitos (5 incidências).

Gráfico 24 - Classificação da pena de interdição temporária de direito fixada na sentença, nas Comarcas de menor porte do Estado do Tocantins, em execuções penais baixadas em 2015 e 2016.

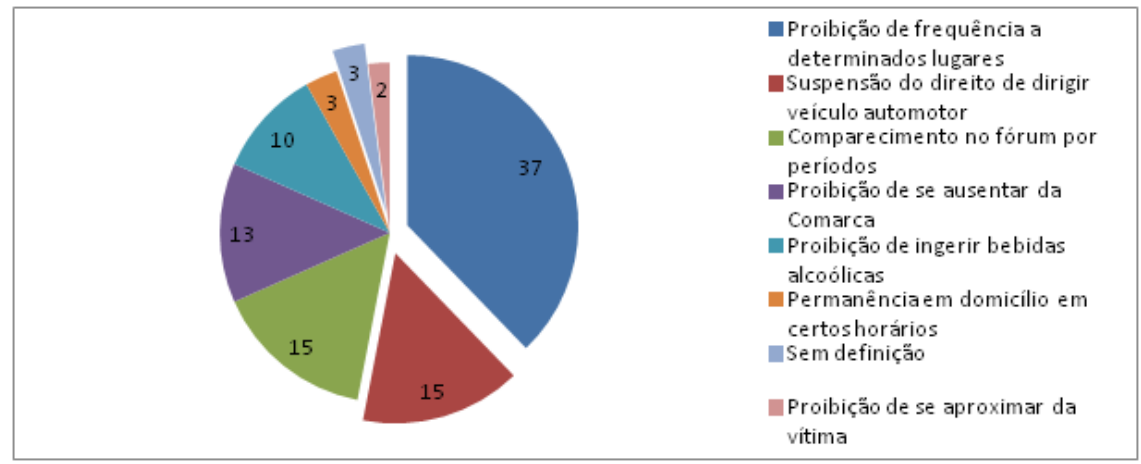

Fonte: Elaborada pelo autor a partir de dados obtidos na tabela EP. I 4, extraída do sistema e-Proc TJTO, 2017.

Continuando a descrição das penas alternativas de interdição de direitos, verifica-se que apenas 3\% dos casos (destacado acima) não há definição na sentença, o que evidencia mais segurança dos juízes na aplicação desta pena. 
Foram aplicadas 99 penas de interdição de direitos no total, incluindo as conjuntamente aplicadas.

Em 37\% das hipóteses (destacado no gráfico) proíbem a frequência do réu em determinados lugares (37 casos), geralmente bares, locais onde há venda de bebidas alcoólicas.

Outras interdições de direitos aplicadas funcionam como verdadeiras condições ou medidas cautelares ou efeitos da condenação para que a pessoa condenada se mantenha naquele estado, em regime de cumprimento de pena em liberdade, como se esclareceu no subitem 3.4.7. Relacionada a estes casos, 15\% determinam o comparecimento por períodos ao Fórum ( 5 incidências); I 3\% refere-se à proibição de se ausentar da comarca ( 13 incidências); 10\% tratam da proibição de ingerir bebidas alcoólicas ( 10 incidências); 3\% tratam das hipóteses em que se determina a permanência em domicílio em certos horários (3 incidências); e em 2\% das hipóteses determinam a proibição de o réu se aproximar da vítima ( 2 incidências).

A pena de permanência em domicílio em certos horários suscita observações. Ela se assemelha à pena em regime aberto, geralmente praticada diante da falta plena de estabelecimento próprio, e se assemelha à pena de recolhimento domiciliar aplicada aos crimes ambientais (subitem 3.4.8).

A grande maioria das penas aplicadas em concreto está circunscrita ao que se denominam restrições livres (genéricas), ou seja, não se relacionam diretamente a fatos ou hipóteses em concreto. Aúnica exceção (restrição vinculada - específica) restringe-se à pena de suspensão do direito de dirigir veículo automotor, pois esta está diretamente umbilicada aos delitos de trânsito. 15\% relacionam-se à suspensão do direito de dirigir veículo automotor ( 15 incidências). Isso é plenamente perceptível já que ocorreram exatamente 15 delitos culposos na direção de veículo automotor, como descreve o assento "e-Proc - processos de execução baixados" -, EP.9. Assevere-se que a pena alternativa aplicada nos casos de ora discussão o foi na qualidade de pena principal, e não como pena substitutiva.

Gráfico 25 - Classificação da pena de limitação de fim de semana fixada na sentença (\%), nas Comarcas de menor porte do Estado do Tocantins, em execuções penais baixadas em 2015 e 2016.

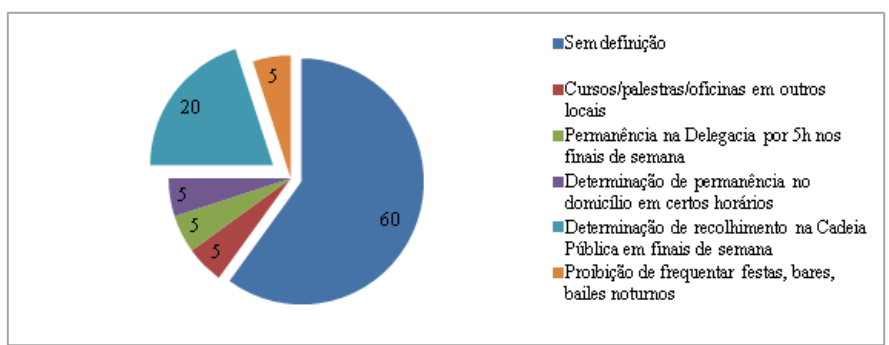

Fonte: Elaborada pelo autor a partir de dados obtidos na tabela EP I 5, extraída do sistema e-Proc TJTO, 2017. 
Demonstrou-se que as penas de limitação de fim de semana são muito pouco aplicadas ( 19 incidências). Representam apenas $5 \%$ de todas as penas alternativas fixadas em sentença (EP.II). Além disso, 60\% delas não são definidas na sentença condenatória, pois os juízes deixam para delimitá-la durante o processo de execução. Essa constatação empírica já era antecipada pela doutrina que entendia pelo "fracasso dessa espécie de pena alternativa, especialmente pela falta de casas do albergado e também de outros estabelecimentos" (GOMES, 2007, p. 81 I ; BITENCOURT, 2007, p. 493). Pesquisa realizada pelo IPEA (20 I 5, p. 7I) chega ao mesmo resultado.

Das que foram definidas, $5 \%$ representam a obrigação de o réu realizar cursos, palestras, ou oficinas em outros estabelecimentos a serem indicados; $5 \%$ refletem a necessidade de permanência na Delegacia de Polícia por 5 horas nos fins de semana; 5\% equivalem à necessidade de permanência em domicílio em certos horários nos fins de semana; $20 \%$ denotam a necessidade de recolhimento na Cadeia Pública em fins de semana; e 5\% correspondem à proibição de frequentar festas, bares ou bailes noturnos nos fins de semana.

A pena de recolhimento na Cadeia Pública em fins de semana encontra-se em dissonância ao apregoado em lei (BRASIL, Lei no 7.210, art. 94, 1984), pela doutrina (REALE JÚNIOR, 20 I3, p. 388), e pela jurisprudência do STJ (HC 208825/SP, 2004), pois se definiu que estabelecimento adequado não deve ser a Cadeia Pública, mas poderia ser o Fórum, o Quartel, a Escola e até a Delegacia se separada da Cadeia Pública.

Pode-se aduzir que nenhuma das penas efetivamente aplicadas corresponde à natureza jurídica da pena de limitação de fim de semana em seu sentido original.

No sentido apregoado neste trabalho, da releitura para a inversão do polo, no sentido de ser o principal objetivo da pena a imposição de medida educativa de comparecimento a programa ou curso educativo, e assim vinculando-se o tempo de permanência em estabelecimento adequado para a realização de tarefas educativas úteis, mas com objetivos positivos e materializados (REALE JÚNIOR, 2013, p. 389; COSTA, 2016, p. I7I), e como indicam as contemporâneas legislações que tratam sobre a violência doméstica e sobre os meios de prevenção e repressão sobre drogas, e ainda com base no princípio da alterabilidade da pena alternativa (BRASIL, Lei n 7.2 10, art. 148, 1984), a pena poderá ter sua finalidade alargada, sendo mais útil e menos custosa à sociedade.

No entanto, conforme se percebe, os resultados empíricos demonstram que tal sentido não foi aplicado no microssistema. Apenas $5 \%$ das hipóteses encaminham para a realização de cursos, que corresponde à irrisória única incidência.

As demais penas aplicadas se confundem com a pena de interdição temporária de direitos, com a diferença de serem aplicadas somente nos fins de semana. 
Gráfico 26 - Penas, medidas ou atividades atinentes à integração social (\%), nas Comarcas de menor porte do Estado do Tocantins, em execuções penais baixadas em 2015 e 2016.

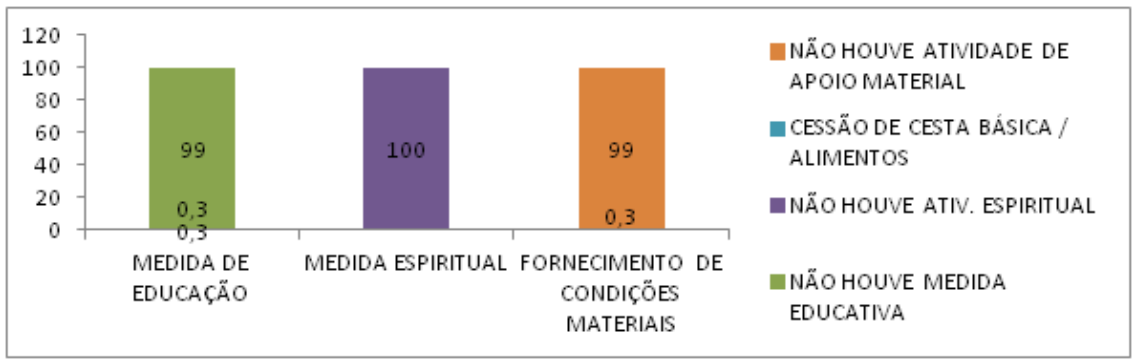

Fonte: Elaborada pelo autor a partir de dados obtidos nas tabelas EP. I 8, EP. I 9, EP.20, extraídas do sistema e-Proc TJTO, 2017.

gráfico acima descreve as ínfimas medidas ou atividades em favor da integração social da pessoa condenada. Pode-se asseverar que as hipóteses para o não encaminhamento ou a não utilização pelos juízes desses ou outros instrumentos que podem ser úteis à inclusão social é: entende-se que a lei não prevê tais possibilidades; ou entende-se que não é a finalidade da pena criminal; ou entende-se que não é a incumbência do sistema de persecução penal.

Há evidências de que os componentes do microssistema não entendem ou não agem com o objetivo de proporcionar condições à harmônica integração social. Aparentemente não há a preocupação com a integração social, segundo os presentes resultados. As respostas empíricas nesta pesquisa demonstram ou que a ressocialização não seria objetivo da pena (o que estaria correto), ou que a ressocialização, a partir da visão tradicional, seria propiciada a partir da adequação social do réu com a punição (o que estaria equivocado) (SÁ, 20।5). De qualquer forma, não há preocupação com o requisito anterior necessário para tal fim, acerca da inclusão social. Ou seja, aduz-se que a pena criminal não tem esse fim ou que, com o cumprimento da punição, o réu estaria ressocializado.

Embora não haja bases paradigmáticas legais que determinem ao juiz a realização de estudos e a viabilização de medidas práticas em prol da inclusão social da pessoa condenada, a partir das conceituações teóricas criminológicas adotadas, pode-se notar que o resultado obtido dirige-se ao caminho da inefetividade.

\section{CONSIDERAÇÕES FINAIS}

A eficiência e a eficácia do processo penal estão diretamente imbricadas com a organização do serviço, por sua estrutura, pessoas e recursos materiais, estabelecimento e cumprimentos dos fluxos e procedimentos padrões e controle dos indicadores. 
De forma geral, no aspecto estrutural, das tarefas, métodos e funções, há um médio grau de eficiência, porém, não há correspondência com o cumprimento dos prazos processuais, que se demonstraram irrazoáveis. A maior parte das penas aplicadas é alternativa e não encarceradora. $O$ serviço na fase da aplicação da pena funciona relativamente bem.

Nos meandros da análise da estrutura, constataram-se haver os meios razoavelmente necessários e adequados para o bom desempenho dos resultados, como a quantidade de pessoas, prédio e salas próprias, local climatizado por condicionadores de ar e equipamentos eletrônicos (estações de trabalho) suficientes para o desempenho das funções de cada servidor, em um ambiente de plataforma eletrônica de processos.

Além do conjunto normativo que rege as tarefas, processos e métodos executados, nesta fase, há normas administrativas de orientação editadas por órgãos superiores ou reguladores. No entanto, não há atuação pragmática no que concerne ao acompanhamento e ao controle dos processos, métodos e resultados por parte desses órgãos. Ter métodos e procedimentos escritos é um passo importante para a organização do serviço. O controle dos métodos e seus resultados, doutro modo, têm a mesma equivalência de relevância para garantir a eficiência e a eficácia do microssistema.

Com relação ao fluxo e rotinas procedimentais, no quesito tempo, observou-se um excesso relevante de prazos processuais, e entre seus procedimentos, considerando-se o paradigma aritmético legal, e também se observando o critério da razoabilidade, o que corrobora para o alto grau de ineficiência nesse quesito.

Evidenciou-se que o alto grau dessa desconformidade não tem correspondência preponderante com os fatores organizacionais investigados (estrutura física e força de trabalho), nem estaria conectado em si aos graus de complexidade do processo (campo de direito material e processual), principalmente quando se observam os graus relevantes de ineficácia correspondentes ao fator tempo. Compreende-se não haver complexidades no decorrer do processo que justifiquem o extravasamento do tempo legal.

No entanto, não se estabeleceu uma relação conclusiva entre essa desconformidade e parte dos fatores organizacionais investigados (estrutura física, força de trabalho), pois os processos investigados foram extraídos em período que se desenvolveu em até dez anos, e os estudos acerca especialmente da estrutura do serviço foi mais recente, ou seja, não plenamente compatibilizados. A melhoria da estrutura e das rotinas, de acordo com os anos, e a instalação do sistema 100\% eletrônico pode indicar ou tende a fomentar a melhoria dos resultados da referida variável nos anos vindouros. Outros fatores de qualquer forma devem ser investigados.

Na aplicação da pena criminal propriamente dita demonstraram-se a ocorrência de algumas conformidades e desconformidades na rotina, processo ou método utilizado.

Verificou-se que a extrema maioria das hipóteses em que as sentenças foram condenatórias a pena principal foi privativa de liberdade e o regime fixado foi aberto, o 
que se compatibiliza com a situação em abstrato e com o objeto limite da pesquisa. Apurou-se que na maior parte dos casos houve substituição para pena alternativa, sendo quase mínima a utilização do instrumento da suspensão condicional da pena e da multa solitária.

Outro dado relevante é que a maior parte dos processos e das penas aplicadas está dentro do patamar de influência do microssistema e não são encarceradoras. Além disso, apurou-se, depois de se fazer uma comparação entre o microssistema e o sistema geral, que a sua operação constitui redução das medidas encarceradoras, diferentemente do que se apontou em outras pesquisas realizadas no País. $\bigcirc$ índice de encarceramento é bem superior no sistema tradicional. Esses dados revelam um bom grau de eficiência do microssistema.

As penas alternativas são aplicadas com certa organização. Algumas das penas alternativas, com relevância de dados, foram de logo definidas na sentença condenatória, com relação aos critérios quantitativos e/ou qualitativos, como a prestação pecuniária, e a interdição temporária de direitos. Outras, porém, como as penas de prestação de serviços e limitação de fim de semana, não tiveram definição quanto aos referidos elementos de especificação em percentual de forte relevância, o que pode ser um demonstrativo de insegurança do juízo quanto à sua definição, muitas vezes diretamente ligada à falta de estrutura para o cumprimento de pena. Como as penas alternativas são focadas em algumas de suas espécies, isso revelou certa ineficiência na ausência da aplicação de outras penas alternativas, aparentemente por falta de estrutura.

O tempo das penas de prestação de serviços substituídas foi compatível com a pena privativa de liberdade aplicada. $\bigcirc$ valor das penas de prestação pecuniária, ao contrário, demonstra a incompatibilidade da lei com a aplicação da pena no caso concreto, pois mais da metade delas foi aplicada abaixo ou em até um salário mínimo legal, o que evidencia que boa parte dos juízes aplica a pena conforme apenas a presunção da pouca capacidade econômica da pessoa condenada. Essa forma de medição gera desproporcionalidade, o que seria uma forma de banalização na aplicação da pena, e acarreta direta violação direta ao princípio da suficiência.

Sobre a prestação pecuniária sugere-se sua preservação no microssistema, tendo em vista sua alta incidência e facilidade de aplicação e de cumprimento, porém, a partir de nova releitura para que haja uma definição lógico-objetiva quanto ao valor de sua incidência, para fins de preservação da igualdade material, da proporcionalidade e do princípio da suficiência da pena alternativa. Quanto mais forem os instrumentos à disposição da justiça, mais possibilidades haverá em favor da aplicação da pena alternativa e, em consequência, do fortalecimento do microssistema.

Sobre a limitação de fim de semana, propõe-se a releitura para a inversão do polo, no sentido de ser o principal objetivo da pena a imposição de medida educativa de comparecimento a programa ou curso educativo, e assim vinculando-se o tempo de permanência em estabelecimento adequado para a realização de tarefas educativas úteis, mas com objetivos positivos e materializados. 
Há, portanto, relativa eficiência na rotina de aplicação geral das penas alternativas, independentemente das releituras acima detalhadas, já que na grande maioria dos casos as regras de cominação são respeitadas quanto à quantidade de penas alternativas, verificando certa prevalência das penas de prestações de serviços, que, segundo pesquisas, são as que mais integram o indivíduo na sociedade, o que se compatibiliza com outras pesquisas realizadas no País.

De outra forma, foram raras as penas alternativas que determinaram o encaminhamento para estudo ou treinamento de alguma técnica. Do mesmo modo, foram ínfimas ou quase nulas as medidas ou atividades que de alguma forma poderiam direcionar a pessoa condenada em favor da integração social ou da inclusão social.

A eficácia do microssistema foi avaliada sob as perspectivas, gerencial e normativa.

Sob a perspectiva gerencial, há um grau relevante de ineficácia, constatado por meio de resultados que geraram duas espécies de desconformidades nos quocientes esperados, ambas contrárias ao cumprimento dos objetivos do processo penal: o veredicto de mérito, aquele em que se declara a inocência ou a culpa.

A primeira é traduzida pelo índice de mais de um terço das hipóteses de prescrições da pretensão punitiva $(35,3 \%)$ e, ao mesmo tempo, em índice abaixo da metade de produção de veredictos de mérito $(43,6 \%)$.

A segunda revela a aplicação de medidas despenalizadoras, depois de iniciada a ação penal (especialmente depois de o recebimento da denúncia), em contraste com a lei e com as interpretações jurídicas possíveis, embora o grau de incidência destas que impactou a ineficácia seja baixo (1,7\%). Essas práticas demonstraram um desvio de caminho paradigmático legal e, portanto, a descompatibilização com a rotina traçada, atacando também, de forma direta, o parâmetro da eficiência.

Outra situação constatada de ineficácia, respeitante ao equilíbrio e justiça, é a aplicação da pena de forma mais branda do que o estabelecido no caso em concreto. $\bigcirc$ estudo não propiciou um resultado conclusivo. No entanto, há evidências de que tal situação ocorreu com certa frequência. A primeira evidência está adstrita à aplicação da maior parte das penas de prestação pecuniária (55\%) em valor abaixo do mínimo legal ou de até um salário-mínimo, o que demonstra incompatibilidade com a lei. Há indicações de que parte dos juízes não se baseia na proporcionalidade entre a pena privativa de liberdade fixada na sentença e o valor mínimo e máximo da pena pecuniária.

A aplicação de penas de interdição de direitos de forma genérica (63\% dos casos), e sem a orientação, acompanhamento e fiscalização, contínuas (97,9\% dos processos), também é outra situação que demonstra o desequilíbrio, como a proibição de frequência do réu em determinados lugares, a proibição de se ausentar da comarca, a proibição de ingerir bebidas alcoólicas, e a determinação para a permanência em domicílio em certos horários.

Constatou-se certo grau de ineficácia no aspecto normativo, em vários momentos da pesquisa. Três situações foram encontradas e analisadas. 
A primeira trata da pena de limitação de fim de semana. Houve pouca adoção pelos destinatários da norma, especialmente dos operadores de direito, no microssistema no universo pragmático, o que corrobora para sua ineficácia.

A outra se refere às medidas de ressarcimento à vítima. Embora a lei determine que o juiz, na sentença condenatória, fixe o valor mínimo para reparação dos danos causados pela infração penal; considerando os prejuízos sofridos pelo ofendido, foram ínfimas as hipóteses em que isso ocorreu. A não atenção à vítima continua sendo uma perseverante no processo penal, por não ser ouvida. Nesse cenário, reconhecendo a importância de tal medida a fim de pacificar o conflito social e restaurar a paz social, no sentido de viabilizar medida ressarcitória, propõe-se, da mesma forma que se alterou o disposto no art. 387, IV, do CPP, alterar o art. 4I do CPP, para incluir a necessidade de argumentação e pedido de ressarcimento nas hipóteses em que há vítima concreta e há danos, morais ou materiais. Ou seja, embora a norma em discussão seja válida, não se extrai efeitos dela.

Como se tratou acima, entre as medidas despenalizadoras aplicadas em contraste com a lei, o que chama a atenção, envolvem algumas hipóteses atinentes à violência doméstica contra mulher. Está consolidada no sistema jurídico brasileiro que a violência doméstica contra mulher exige tratamento diferenciado e, por isso, a Lei n ${ }^{\circ}$ | I .340, de 2006, tratou de estabelecer instrumentos jurídicos que consideraram essas particularidades. Essas diferenças foram reconhecidas constitucionais pela Suprema Corte. No entanto, com o uso de fundamentação genérica ou sem embasamento legal compatível, em alguns casos, a diferenciação de tratamento não foi observada, e alguns processos foram extintos. Ressalte-se que essas práticas foram realizadas apenas em algumas comarcas, em estado minoritário e em índice não relevante.

Diante dos resultados de ineficácia contínua, pode-se asseverar que acompanha tal decorrência o parâmetro da efetividade. Há fortes evidências de que há uma contínua ineficácia do microssistema, na fase processual da cognição, especialmente porque os processos analisados são de diversos anos.

\section{REFERÊNCIAS}

BITENCOURT, Cezar Roberto. Tratado de direito penal. I I. ed. São Paulo: Saraiva, 2007.

BRASIL. Conselho Nacional de Justiça. Regras de Tóquio - regras mínimas das Nações Unidas para a elaboração de medidas não privativas de liberdade. Brasília, DF, 20 I 6. 24 p. - (Série Tratados Internacionais de Direitos Humanos). Disponível em: <http://www.cnj.jus.br/files/conteudo/arquivo/20 I 6/09/6ab7922434499259ffca072 9122b2 d38.pdf>. Acesso em: 15 mar. 2017. 
BRASIL. Conselho Nacional de Justiça. Resolução n 213, I5 de dezembro de 2015. Dispõe sobre a organização e o funcionamento dos Grupos de Monitoramento e Fiscalização (GMF) nos Tribunais de Justiça dos Estados, do Distrito Federal dos Territórios e nos Tribunais Regionais Federais. Disponível em: $<$ http://www.cnj.jus.br/busca-atos-adm?documento $=306 \mathrm{I}>$. Acesso em: 15 mar. 2017.

BRASIL. Constituição, 5 de outubro de 1988. Constituição da República Federativa do Brasil. Disponível em: < http://www.planalto.gov.br/ccivil_03/constituicao/constituicao compilado.htm >. Acesso em: 15 mar. 2017.

BRASIL. Decreto-lei no 2848, 7 de dezembro de 1940. Institui o Código Penal. Disponível em: < http://www.planalto.gov.br/ccivil_03/decreto-lei/Del2848.htm>. Acesso em: 14 abr. 2018.

BRASIL. Decreto-Lei no 3688, de 03 de outubro de 194I. Lei das contravenções penais. Disponível em:< http://www.planalto.gov.br/ccivil_03/decretolei/Del3688.htm > . Acesso em: I 4 abr. 2018.

BRASIL. Decreto-Lei n 3689, de 03 de outubro de 194I. Código de Processo Penal. Disponível em:< http://www.planalto.gov.br/ccivil_03/decretolei/Del3689Compilado.htm >. Acesso em: 14 abr. 2018.

BRASIL. IBGE. Instituto Brasileiro de Geografia e Estatística. Dados dos municípios de pequeno porte. Brasília. Disponível em < www.ibge.gov.brhomepresidenci anoticiasimprensappts000000064>. Acesso em 23.4.20 I8.

BRASIL. Lei 7.2 I0, I I de julho de 1984. Institui a Lei de Execução Penal. Disponível em: <http://www.planalto.gov.br/ccivil_03/Leis/772 10.htm>. Acesso em: I 5 mar. 2017.

BRASIL. Lei 9.099, 26 de setembro de 1995. Dispõe sobre os Juizados Especiais Cíveis e Criminais e dá outras providências. Disponível em: <http://www.planalto.gov.br /ccivil_03/Leis/L9099.htm>. Acesso em: I 5 mar. 2017.

BRASIL. Lei 97।4, 25 de novembro de 1998. Altera dispositivos do Decreto-Lei $n^{\circ}$ 2.848, de 7 de dezembro de 1940 - Código Penal. Disponível em: <http://www. planalto.gov.br/ccivil_03/Leis/L97|4.htm>. Acesso em: I 4 abr. 20 I 8.

BRASIL. Lei 10259, 12 de julho de 2001. Dispõe sobre a instituição dos Juizados Especiais Cíveis e Criminais no âmbito da Justiça Federal. Disponível em: <http://www.planalto.gov.br/ccivil_03/Leis/LEIS_200 I/LI 0259.htm> . Acesso em: I4 abr. 2018. 
BRASIL. Lei I 1340, 07 de agosto de 2006. Cria mecanismos para coibir a violência doméstica e familiar contra a mulher, nos termos do $\S 80$ do art. 226 da CF, da Convenção sobre a Eliminação de Todas as Formas de Discriminação contra as Mulheres e da Convenção Interamericana para Prevenir, Punir e Erradicar a Violência contra a Mulher; dispõe sobre a criação dos Juizados de Violência Doméstica e Familiar contra a Mulher; altera o Código de Processo Penal, o Código Penal e a Lei de Execução Penal; e dá outras providências. Disponível em: < http://www.planalto. gov.br/ccivil_03/_ato2004-2006/2006/lei/I I 340.htm>. Acesso em: I 4 abr. 20 I 8.

BRASIL. Lei I|419, 19 de dezembro de 2006. Dispõe sobre a informatização do processo judicial; altera a Lei no 5.869, de I I de janeiro de 1973 - Código de Processo Civil; e dá outras providências. Disponível em: <http://www.planalto.gov.br /ccivil_03/_ato2004-2006/2006/lei/I I 4 | 9.htm >. Acesso em: | 4 abr. 20 I 8.

BRASIL. Lei Complementar n 80, 12 de janeiro de 1994. Organiza a Defensoria Pública da União, do Distrito Federal e dos Territórios e prescreve normas gerais para sua organização nos Estados, e dá outras providências. Disponível em: <http://www.planalto.gov.br/ccivil_03/leis/lcp/Lcp80.htm>. Acesso em: 4 abr. 20 I 8.

BRASIL. Supremo Tribunal Federal. Recurso Extraordinário n 64I 320, I I de maio de 2016. Relator: Ministro Gilmar Mendes. Tribunal Pleno. Disponível em: <http://www.stf.jus.br/portal/jurisprudencia/visualizarEmenta.asp?s | =0003 | 3908\&b ase $=$ baseAcordaos $>$. Acesso em: 13 mar. 2018.

BRASIL. Supremo Tribunal Federal. Súmula Vinculante $n^{\circ}$ 56, 29 de junho de 20 I6. A falta de estabelecimento penal adequado não autoriza a manutenção do condenado em regime prisional mais gravoso, devendo-se observar, nessa hipótese, os parâmetros fixados no RE 64l.320/RS. Disponível em: < http://www.stf.jus.br/portal/juris prudencia/menuSumario.asp?sumula $=3352>$. Acesso em: 13 mar. 2018.

BRASIL. Supremo Tribunal Federal. Súmula $n^{\circ} 719,24$ de setembro de 2003. A imposição do regime de cumprimento mais severo do que a pena aplicada permitir exige motivação idônea. Disponível em: <http://www.stf.jus.br/portal/jurispru dencia/menuSumarioSumulas.asp?sumula =2556>. Acesso em: 13 mar. 2018.

BRESSER-PEREIRA, Luiz Carlos. A reforma gerencial do Estado de 1995. Revista de Administração Pública (RAP). Rio de Janeiro, RJ: Fundação Getúlio Vargas-FGV, 2000, v. 34, n. 4, jul./ago., 2000, p. 07-26.

CAPEZ, Fernando. Curso de direito penal. Volume I. I 8. ed. São Paulo: Saraiva, 2014. CARPINETTI, Luiz Cesar Ribeiro; GEROLAMO, Matheus Cecílio. Gestão da Qualidade ISO 9001 : 201 5. São Paulo: Atlas, 2017. 
CHIAVENATO, Idalberto. Teoria geral da administração. Abordagens prescritivas e normativas. 7.ed., v. I. Barueri: Manole, 2014.

COSTA, Álvaro Mavrink. Execução penal. Rio de Janeiro: LMJ Mundo Jurídico, 2016.

GAGLIARDI, Ricardo. O princípio da razoável duração do processo e a prescrição penal: um estudo de caso na Comarca de Colmeia, Estado do Tocantins. In: MELO, José Wilson Rodrigues de; ROCHA, Suyene Monteiro da; FERNANDES, Suzidarly Ribeiro Teixeira. Caminhos e olhares sobre os direitos humanos. Curitiba: CRV, 20 17. 258p. p.209-233.

GAGLIARDI, Ricardo. Microssistema de penas criminais alternativas nas comarcas de menor porte do Estado do Tocantins: diagnóstico, tendências e proposições. 2018. 402f. Dissertação de mestrado em prestação jurisdicional e direitos humanos. Universidade Federal do Tocantins, 2018.

HABER, Carolina Dzimidas. A eficácia da lei penal: análise a partir da legislação penal de emergência (o exemplo do regime disciplinar diferenciado). 2007. I64f. Dissertação. (Departamento de Ciências Políticas) - Faculdade de Filosofia, Letras e Ciências Humanas, Universidade de São Paulo, São Paulo, 2007.

ILANUD. INSTITUTO LATINO AMERICANO DAS NAÇÕES UNIDAS PARA PREVENÇÃO DO DELITO E TRATAMENTO DO DELINQUENTE. Levantamento Nacional Sobre Execução De Penas Alternativas - Relatório Final de Pesquisa. 2006. 286 p. Disponível em: <file://C:/Users/Tribunal/Downloads/PenasAlternativas ILANUD

completo.pdf >. Acesso em: 15 mar. 2018.

IPEA. INSTITUTO DE PESQUISA ECONÔMICAAPLICADA. A Aplicação de penas e medidas alternativas - relatório de pesquisa. Rio de Janeiro - Secretaria de Assuntos Estratégicos: Livraria do Ipea, 2015. 100 p. Disponível em: <http://repositorio.ipea.gov.br/handle/l I058/75 I7>. Acesso em: I 5 mar. 2018.

MIRABETE, Julio Fabrini. Execução penal. I 0. ed. São Paulo: Atlas. 2002.

NARDO, Diogo. Tocantins: diagnóstico e proposta de unificação ao regime semiaberto na terceira entrância do Estado do Tocantins. Rio de Janeiro: Gramma, 2017.

NUCCI, Guilherme de Souza. Manual de direito penal: parte geral - parte especial. 4. ed. São Paulo: Revista dos Tribunais, 2008. 
OLIVEIRA, Fabiana Costa et al. Medidas alternativas: estrutura necessária para aplicação, fiscalização e avaliação. Boletim Científico. Jan./mar. 2002. p. 53-67.

PIRES, Alvaro P.; DIGNEFFE, Françoise. Vers un paradigme des inter-relations sociales? Pur une reconstruction du champ criminologique. Criminologie, v. 25, n. 2, p. 13-47, 1992.

REALE JÚNIOR, Miguel. Instituições de direito penal. Rio de Janeiro: Forense. 2013.

SÁ, Alvino Augusto de. Criminologia clínica e execução penal: proposta de um modelo de terceira geração. 2. ed. São Paulo: Saraiva. 2015.

SICA, Leonardo. Direito penal de emergência e alternativas à prisão. São Paulo: Revista dos Tribunais. 2002.

TOCANTINS. Lei Complementar n 10, I I de janeiro de 1996. Institui a Lei Orgânica do Poder Judiciário do Estado do Tocantins e dá outras Providências. Disponível em: < h t t p : / / w w w. t j to.jus.br/joom latools-files/docman files/arquivos/legislacao_interna/leis/lei_complementar_10_96.pdf $>$. Acesso em: 8 abr. 2018.

TOCANTINS. SEPLAN. Secretaria do Planejamento e Orçamento do Estado do Tocantins. Temperatura Média Anual do Ar. 2018. Disponível em: <http://web.seplan.to.gov.br/Arquivos/download/ZEE/Estado_do_Tocantins_Mapas A0_20I5/Temperatura_Ar_Media_Anual_TO_20I5.pdf >. Acesso em: 30.5.20 I 8.

TOCANTINS. Tribunal de Justiça do Estado do Tocantins, Comarcas de $1^{\mathrm{a}}$ e $2^{\mathrm{a}}$ Entrâncias. Processo eletrônico administrativo - SEI n 17.0.0000074I3-6. Palmas, 2017.

TOCANTINS. Tribunal de Justiça do Estado do Tocantins, Coordenadoria de Gestão Estratégica, Estatística e Projetos. Processo eletrônico administrativo - SEI $\mathrm{n}^{\circ}$ 17.0.000007408-0. Palmas, 2017.

TOCANTINS. Tribunal de Justiça do Estado do Tocantins. Corregedoria-Geral de Justiça. Provimento $n^{\circ}$ 12, 15 de agosto de 2012. Institui o Manual de Procedimentos Penais do Estado do Tocantins. Disponível em: <http://wwa.tjto.jus.br/elegis/Home/Imprimir/598>. Acesso em 3 I mar.20 8. 
TOCANTINS. Tribunal de Justiça do Estado do Tocantins. Gabinete da Presidência e Corregedoria-Geral de Justiça. Portaria-Conjunta n 196/2009, I I de maio de 2009. Constitui o Grupo de Monitoramento Acompanhamento e Aperfeiçoamento do Sistema Carcerário GMF. Disponível em: < http://wwa.tjto.jus.br/elegis/Home/lm primir/647>. Acesso em: I 5 mar. 2018.

TOCANTINS. Tribunal de Justiça do Estado do Tocantins. Gabinete da Presidência e Corregedoria-Geral de Justiça. Portaria $n^{\circ} 444 / 2012$, 29 de junho de 20 I2. Institui o Grupo de Monitoramento e Fiscalização do Sistema Carcerário GMF. Disponível em: < http://wwa.tito.jus.br/elegis/Home//mprimir/550 > . Acesso em: I 5 mar. 20 I 8.

TOCANTINS. Tribunal de Justiça do Estado do Tocantins, Portaria $\mathrm{n}^{\circ}$ 786, 19 de abril de 2018. Consolida as normativas que tratam da competência, estrutura e funcionamento do Grupo de Monitoramento e Fiscalização do Sistema Carcerário GMF, no âmbito do Poder Judiciário do Estado do Tocantins. Disponível em: <http://wwa.tjto.jus.br/elegis/Home/lmprimir/l 446>. Acesso em: I 5 mar. 2018.

TOCANTINS. Tribunal de Justiça do Estado do Tocantins. Portaria 1656//2014. Palmas, $20 \mid 4$.

TOCANTINS. Tribunal de Justiça do Estado do Tocantins. Portaria 1859, de 17.05.20 16. Instituiu o Grupo Gestor das Equipes Multidisciplinares (GGEM), com a finalidade de gerenciar os trabalhos desenvolvidos pelas equipes multidisciplinares. Palmas, 2016.

TOCANTINS. Tribunal de Justiça do Estado do Tocantins. Portaria 2056//2014. Palmas, 2014.

TOCANTINS. Tribunal de Justiça. Resolução n 05, 08 de agosto de 2003. Dispõe sobre a criação da Central de Execuções de Penas e Medidas Alternativas da Comarca de Palmas. Disponível em: < http://wwa.tjto.jus.br/elegis/Uploads/Reso005200 3.pdf>. Acesso em: 15 mar. 2018.

TOCANTINS. Tribunal de Justiça. Resolução n I0, 06 de maio de 20 I 0. Dispõe sobre a criação da Central de Execução de Penas e Medidas Alternativas das Comarcas de Gurupi e Araguaína e dá outras providências. Disponível em: < http://wwa.tjto.jus.br/elegis/Home/Imprimir/35I > . Acesso em: 15 mar. 2018. 
TOCANTINS. Tribunal de Justiça. Resolução n 16, 20 de novembro de 2008. Dispõe sobre a criação da Central de Execução de Penas e Medidas Alternativas da Comarca de Porto Nacional e dá outras providências. Disponível em: $<$ http://www.tjto.jus.br/index.php/docman-lista/resolucoes-passadas- I/resolucoes3/4 |4-resolucao-n-16-2008-dispoe-sobre-a-criacao-da-central-de-execucao-depenas-e-medidas-alternativas-I/file> . Acesso em: 15 mar. 2018.

TRIOLA, Mário F. Introdução à estatística. Rio de Janeiro: LTC, 2005. 
